Makale Geliş | Received: 24.03.2020.

Makale Kabul|Accepted: 06.04.2020.

DOI: $10.18795 /$ gumusmaviatlas.708719

Mavi Atlas, 8(1)2020: 189 - 214

Araştırma Makalesi|Research Article

\author{
İstanbul Ticaret Üniversitesi, İşletme Fakültesi, İktisat Bölümü, İstanbul, TÜRKIYYE \\ Istanbul Commerce University, Faculty of Business, Economics. Istanbul, TURKEY
}

Şefik MEMIS

Öğr. Gör. Dr.|Lecturer Dr.

ORCID: 0000-0002-6926-2215

smemis@ticaret.edu.tr

\title{
Unutulanları Hatırlamak için Yapılan Fuar: 1863 Sergi-i Umûmî-i Osmanî (Osmanlı Genel Sergisi) \\ Öz
}

Osmanlı'nın modern anlamda ilk fuar katılımı 1851 Londra Dünya Fuarı'na olurken, düzenlediği ilk ulusal fuar da, 1863 yllında Sultanahmet Meydanında açılan Sergi-i Umûmî-i Osmanî ya da Osmanlı Genel Sergisi idi. Bu sergi, Osmanlı sanayileșme hamlesi için Islah-1 Sanayi Komisyonunun belirlediği yol haritasının şartlarından biri olan fuar açılmasının teşvik edilmesi ilkesinin bir sonucuydu. Aynı zamanda Avrupa ülkelerindeki gelişmeleri yakından takip eden padişah ile Osmanlı bürokrasinin çağını yakalama arzusunun tezahürüydü. 1863 Sergisi her bakımdan ilklere ev sahipliği yapacaktı. İlk kez bir sergi binası inşa edildi. İlk kez özel sektörün ve padişahın sağladığı maddi imkanla fuarın finansmanı yapıldı. İlk kez bir sergi tüzüğü hazırlanarak, herkesin buna uyması sağlandı. Ama hepsinden önemlisi, ilk kez Osmanlı'ya has bir sergi iç dizaynı, yani fuar tasarımı yapıldı. İç düzenlemeler ile teşhir dolapları tasarlandı, imal edildi ve ücretle üreticilere kiraya verildi. Çevre düzenlemesi yapıldı. Ziyaretçilerin kontrol edilip sayılabilmesi için ilk kez turnike sistemi kullanıldı. Fuar alanındaki bu ilklerin yanı sıra ekonomide yol açtığı etkiler de ilkler oluşturdu. İlk kez Osmanlı İmparatorluğunun bütün vilayetlerinden, yani günümüzde 40’tan fazla devletin yer aldığı coğrafyadan toplanan 15 bin çeşitten fazla ürün İstanbul'a getirilerek bir envanter çıkarıldı. Tarımsal üretimin yanı sıra sanayi üretimi için de ciddi bir politika oluşturulmasına zemin hazırlandı. Açılışını Sultan Abdülaziz’in yaptı̆̆1 1863 Sergisi ürünlerinden tasarımına kadar Türkiye'nin köklü fuarcılık birikimini ortaya koyuyor. Ama en önemlisi de Türkiye'nin uzun süredir kaybettiği üretme kabiliyetini yeniden kazandırmak gibi iddialı bir vazifeye sahipti.

Anahtar Kelimeler: Sergi, Sergi-i Umumi-i Osmani, 1863 Sergisi, Sanayi, Fuarc1lik.

\section{Exhibition to Remember What We Have Forgotten: 1863 Ottoman General Exhibition}

\section{Abstract}

While the first participation of the Ottoman Empire to an exhibition in the modern sense was in 1851 at the London World Fair, the first national fair it ever organized was the Sergi-i Umûmî-i Osmanî or Ottoman General Exhibition, which opened in Sultanahmet Square in 1863. It was also a manifestation of the desire of the sultan, who closely followed the developments in European countries and the Ottoman bureaucracy to catch up with the times. The 1863 Exhibition would host many "firsts" in all respects. For the first time, an exhibition building was built. For the first time, the fair was financed with the financial means provided by the private sector and the sultan. It was the first time that an exhibition charter was prepared making everyone to comply with it. But above all, for the first time, an exhibition interior design-a fair design unique to the Ottoman Empire was made. Display cabinets with interior arrangements were designed, manufactured and rented to manufacturers for a fee. Landscaping was done. For the first time, the turnstile system was used to control and count the visitors. Besides these "firsts" in the exhibition area, the impacts the exhibition had on the economy led to other "firsts". For the first time, an inventory was made by bringing more than 15 thousand kinds of products collected from all provinces of the Ottoman Empire. A basis for the establishment of a serious policy for industrial production as well as agricultural production was laid. The 1863 Exhibition of which Sultan Abdülaziz made the opening, with its displayed products and designs revealed Turkey's deeply rooted fair accumulation. But most importantly the exhibition served to help Turkey to regain her production ability and capacity, which she had long lost.

Keywords: Exhibition, Sergi-i Umumi-i Osmani, 1863 Exhibition, Industry, Fairs. 


\section{Fuarcılığın Tanımı ve Tarihsel Gelişimi}

19. yüzyıl gibi oldukça hassas gelişmelerin yaşandığı bir dönemde, Osmanlı İmparatorluğu Batı karşısındaki son ve en önemli hamlesi olarak nitelendirilebilecek sanayileşme çabasına girişirken, yararlandığı en önemli enstrümanlardan biri de uluslararası fuarlara katılım ile bunun izdüşümü olan ulusal ve bölgesel fuarlar düzenlemekti. Osmanlılar, ilk fuarın düzenlendiği 1851 yılında Londra'da yapılan açılış merasiminde çekilen tören fotoğrafinda yerlerini aldılar. Sonrasındaki tüm dünya fuarlarına katıldılar. Hatta Sultan Abdülaziz, 1867 Paris Sergisi'nin açılış törenine katılmak için yurtdışına çıkan ilk Osmanlı padişahı olma vasfını bile kazandı.

Sanayileşmiş ve kalkınmış bir ülke olmaya doğru hızla yol almak için fuarları akıllıca kullanan Osmanlı İmparatorluğu, ilk andan itibaren fuarlara devlet görevlileri gönderdi, raporlar hazırlattı, ülke katılımı olmayan sergileri bile yakından izledi, tüccarın katılımını teşvik etti. Daha da önemlisi, bu fuarların etkisiyle sanayileşmesine yön vermeye çalışırken benzerlerini de yurt içinde yapmaya çalıştı. Bu bağlamda ilk modern ve kapsamlı Osmanlı fuarı ise 1863 Sergi-i Umûmî-i Osmanî oldu. Kısa ismiyle 1863 Sergisi; yerli fuar geleneğini başlatıcı özelliği sebebiyle teşhir edilen ürünlerden fuar ve stand tasarımına, sergi nizamnamesinden ticari sonuçlarına kadar detaylı bir incelemeyi hak ediyor. Bu makalede, bu ayrıntılı inceleme yapilırken, 1863'te İstanbul'da Sergi-i Umûmî-i Osmanî’yi düzenleyenlerin yapmak istediklerinin altı özellikle çizilmeye çalışıldı:

“... Memâlik-i Şâhâne’de yapılmakta olduğu hâlde bir vakitten beri İstanbul'ca unutulan her nev'i eşyayı halka gösterip (hatırlatmak)...”

\section{Fuarın Tanımı}

Latince "festival, bayram, dini tören" anlamına gelen "feriae" kelimesinden türeyen fuar sözcügü, Türkçe’ye Fransızca'daki “foire” sözcüğünden geçmiştir (Aymankuy 2006: 186).Türkçe’de sergi sözcügüule karşılanan fuar, "çeşitli mal, hizmet, sanat eseri ve teknolojik buluşların organize edilmiş şekilde teşhirine" denilmekteydi. En eski fuarlar, "bahar ve yaz mevsimlerindeki veya hasat zamanlarındaki bayramlarda" düzenlenirdi. Bu bağlamda "alıcı ile satıcıların bir araya geldikleri geçici pazar" olarak, belirli dönemlerde, genellikle de y1lın aynı tarihlerinde aynı yerlerde düzenlenirdi (Kılkış 1977: 8).

Fuarın üzerinde uzlaşıya varılabilen tek bir tanımı bulunmuyor. Bunun sebeplerinden biri de fuarcılıkta yaşanan hızlı gelişmenin onun kapsam ve içeriğini değişime uğratmasıdır. Dolayısıyla pazar'dan başlayıp fuar'a ve expo'ya uzanan kavramsal yolculuk, beraberinde farklı tanımları da getirmiştir. Bütün bu tanımları kapsayan en geniş anlamıyla fuar, "ticaretle ilgili ürün ya da hizmetlerin, teknolojik gelişmelerin, bilgi ve yeniliklerin tanıtımı, pazar bulunabilmesi ve satın alınabilmesi, teknik işbirliği, geleceğe yönelik ticari ilişkiler kurulması ve geliştirilmesi için, belirli bir takvime bağlı olarak, düzenli aralıklarla genellikle de aynı yerlerde gerçekleştirilen bir tanıtım etkinliği”" şeklinde tarif edilebilirdi (Bahçetepe 2009: 10).

Panayır, fuar sözcüğ̈nün Türkçedeki karşıllğı olarak görülmüş, ancak 20. yüzyılın ikinci yarısında uluslararası nitelikte olanlardan ziyade ülke içi fuarları isimlendirmek için kullanılmıştı (Kılkış 1977: 9). Aslında Yunancadaki "panegyris" kelimesinden türemiştir. Panegyris ise "Eski Yunan'da bir site, ülke veya kabile/ırka bağlı bütün halk tarafindan ortak bir tapınak etrafinda yapılan toplantı" anlamına gelmekte ve daha çok da olimpiyatlar için kullanılmaktaydı (Nisan 2020).

Osmanl belgelerinde ise panayır, "yllda bir defa ikame olunan panayır tabir olunur pazar" şeklinde tarif edilmişti (Şen 1996: 11). Lütfi Güçer, Osmanlı ticaret politikalarını incelediği kapsamlı makalesinde panayırları, "hafta pazarlarından farklı olarak senede bir veya birkaç defa ve muayyen zamanlarda, bir hafta veya 10 gün gibi bir müddetle açık kalıp oldukça geniş bir bölgenin tüccarlarını ve emtialarını bir arada toplayan pazarlardır” şeklinde tarif ediyordu (Güçer 1987: 44). 


\section{İlk Fuarların Ortaya Çıkışı ve Modern Fuarcılığın Başlangıcı}

Fuarların ortaya çıkış nedeni, mal ve ürünlerin dağıtım sorununu çözmek amacını taşıyordu. Çünkü fuarlarla birlikte "arz ve talebin belirli bir yerde ve zamanda bir araya gelmesi" sağlanmış, böylece üreticinin üretimini satması kolaylaştırılmıştı. Bu ilk pazar yerleri, daha ziyade kasaba sınırları içinde ve mezarlıklarda kuruluyordu. Yerleşim yerine yakın kurulmasının sebebi ise, "ziyaretçi tacirlerin daha az kavgacı ve daha saygın olacağına" dair kuvvetli inançtı. Daha sonraları Roma devrinde fuarlar, hem siyaseti hem de ticareti güçlendirmek amacıyla kullanıldı.Zamanla fuarlar, bölgesel pazarlardan iki yöne doğru gelişti. Bunlardan biri doğrudan ticaretle ilgili olan bir mekân olarak öndegelen kervan yolları kavşaklarıydı. Diğeri ise dini bir içeriğe sahipti, halkın dini bayramlar sebebiyle toplandığ1 yerlerdi (Kılkış 1977: 9). Bu iki yerin temel özelliği de mal ve ürünlerin yani satıcının alıcı ile buluştuğu mekânlar olmasıydı. Birincisinde daha çok tacirler buluşurken, ikincisinde tacir ile tüketici bir araya geliyordu. Farklı bölgelerden ve milletlerden tacirlerin iştirak ettiği fuarlar; ticarette, ölçüde, tartıda, kalitede, üretimde ortak standartların geliştirilip benimsenmesine yol açtı. Tüm bunlar ise ticaretin gelişip yaygınlaşmasını sağladı.Ticaret geliştikçe büyük fuarlar da ortaya çıkmaya başladı. Sözgelimi 629'da Paris yakınlarında Sen Denis Fuar1, 11. yüzyılda Köln'de bahar fuarları, Selanik'te Sen Demetrius, Bizans topraklarında ise Antakya ve Trabzon fuarları dönemin en önemli fuarları olarak kabul ediliyordu. Benzer şekilde Çin'in Manza eyaletinde düzenlenen Kimsai Fuarı ile Rusya'daki Nijninovgorod Fuarı da önemliydi (Kilkış 1977: 10).

Özellikle Akdeniz Avrupası ile Kuzey Avrupa toplulukları arasında mal alım-satımının gerçekleştiği fuarlar, coğrafi konumu son derece önemli olan noktalarda düzenleniyordu. Sözgelimi Ortaçağ’da, 12. yüzyılda Almanya ile bugünkü Batı Avrupa ülkeleri ve İtalya arasındaki ticaret karadan yapılıyordu. Alp geçitlerinden aktarılan malların önemli bir bölümü Leipzig ve Frankfurt panayırlarında, özellikle Champagne bölgesindeki panayırlarda alınıp satılıyordu (Güran 2011: 73). Ayrıca 10. ve 12. yüzyıllar arasında sınâ̂ faaliyetlerin şehir merkezlerine kayması ve artık ihtisaslaşmış kişilerce yapılmasıyla üretimde bir değişim yaşandı. Böylece özellikle dokuma sanayiinde uzak pazarlar için, yani satış amacıyla daha geniş pazarlara yönelik üretim yapılmaya başlandı. Bu da periyodik fuarlar ile düzenli pazarların kurulmasına yol açtı. Bunların yerini daha sonra, ticaret merkezi olan şehirler ald1 (Güran 2011: 76).

Mecmua-i Fünûn'da, 1863 Sergi-i Umûmî-i Osmanî’nin düzenlenmesi vesilesiyle sergilerin tarihine ilişkin yayınlanan bir makalede, sergilerin başlangıcı eski Yunan'a kadar götürülüyor bazı Yunan sanatçılarının eserlerini halkın görebileceği şekilde teşhir ettiği belirtiliyordu. 1799'da benzer şekilde bir Fransız sanatçı tarafindan sanat eserlerini teşhir için sergiler açılmıştı. Halka, dolayısıyla ilgilisine gösterme ve sunma yöntemi olarak o dönemde kabul gören sergi, daha sonra ise üretim alanına, yani ticarete uyarlanmıștı: "Sınâyiin terakkisi hakkında işbu tedbirin hüsn-i te'sirâtı görüldüğünden birinci defa olmak üzere 1798 senesi Paris'te Fransa'nın her nev'i mamulât ve mahsulâtına mahsus bir sergi küşad kılındı" (Kadri Bey 1863: 386). Daha sonraları her sene veyahut iki üç senede bir kere Paris'te buna benzer sergiler açılmaya başlandı, büyük faydalar sağladığı müşahade edilince sergi adeti bütün Avrupa'ya yayıldı ve "1860 senesi Belçika'da ve 1834 senesi Berlin'de ve 1835 senesi Viyana'da bu misillû husûsî ve muahharan 1851 senesi Londra'da, 1855 senesi Paris'te ve 1862 senesi defa-i sâniye olarak yine Londra'da umûmi sergiler küşad” olundu (Kadri Bey 1863: 387).

\section{Türklerde Fuarcılık}

Türkler'in uluslararası fuarlarda görünmesi ise çok eski zamanlara kadar uzanmaktaydı. Ortaçağ Avrupa'sında fuarlara tacir olarak katılan Türkler, bu fuarlarda tekstilden silah sanayiine kadar çeşitli sektörlerdeki ürünlerini satışa sunarlardı. René Poirier'in araştırmalarına göre Türkler Fransa'daki Beaucaire, Almanya'daki Leipzig, Rusya'daki Nijininogorod fuarlarına katılip burada kumaş, deri, halı, mücevherat, kemer ve silah gibi malları satışa sunmuşlardı (Kılkış 1977: 17). 
Türkler'de Selçuklu Dönemi'yle birlikte İslam dünyasından elde edilen pazar-panayır geleneği ile beraber Doğu ile Batı, Kuzey ile Güney arasındaki ticaret yollarının geçtiği Anadolu topraklarında bulunmanın sağladığı avantajla, köklü bir fuar geleneği oluştuğu söylenebilir. Selçuklu Dönemi'nde panayırlar ya uluslararası ticaret yolları üzerinde ya orduların konakladığı mekânlarda (Yabanlu Pazarı gibi), ya sınır boylarında ya da şehrin dışında kuruluyordu. Bu panayırlar mevsimli ve geçici nitelikteydi. Ülgen'e göre (Ülgen'den aktaran Kılkış 1977: 363, 379), Anadolu'daki pazar ve panayırlarda, transit ticaretin odak noktasında olmaktan kaynaklanacak şekilde, uzak mesafe ticaretine yönelik mal ve ürünler satılırdı. Yine ona göre Anadolu'da kurulan pazarlarda Orta Asya, İran ve Bizans geleneklerinin izleri görülürdü. Anadolu coğrafyasında var olan her kültür, buradaki pazar ve panayır oluşumunu etkilemişti.

Bu noktada ifade etmek gerekir ki Anadolu'nun Bizans'tan Türklere geçiş döneminde ve öncesinde, bu topraklar iktisaden sönük günler geçiriyordu. Güvensiz ticaret yollarının yanı sıra Müslümanlar ve Türkler ile sürekli savaş hâlinin bu durumda etkisi büyüktü. Selçuklular ile birlikte Anadolu'da ticari canlanma başladı. Antalya'dan Sinop ve Samsun'a doğru genişleyen Selçuklular, Karadeniz kıyı şehirlerini güvenli ticaret merkezleri hâline getirdiler. Anadolu'dan geçen ticaret güzergâhlarına kervansaraylar inşa ederek, konaklayan tüccar ve yolculara ücretsiz hizmetler sunulmasına özen gösterdiler. Türkistan'daki geleneklerin Anadolu'ya uyarlanması olan kervansarayların yanı sıra birçok köprü de inşa edildi. Selçuklular, Batı-Doğu Yolu ve Kuzey-Güney Yolu ile Anadolu'yu milletlerarası ticaretin içine tekrar dahil etmeyi başardılar. Özellikle KuzeyGüney Yolu sayesinde Karadeniz, yani kuzey ülkelerinden gelen tüccarlar Sinop üzerinden Sivas'a, oradan Kayseri'ye ve Konya'ya kolayca ulaşabiliyorlardı. Bu güzergâh özellikle Yabanlu Pazarı'na gelen tüccarlar için büyük kolaylık sağllyordu. Doğulu ve Batılı tüccarlar daha çok Sivas'ta buluşuyorlardı. Bunlar arasında Venedik, Ceneviz, Napoli, Piza gibi şehir cumhuriyetlerine mensup tüccarlar ile Bizans, Rus ve Kıpçak tüccarları da bulunuyordu (Kılkış 1977: 2-5).

Selçuklu Dönemi'nin en meşhur pazarlarından biri olan Yabanlu Pazarı, Anadolu'nun iki önemli ticaret yoluyla da kolayca ulaşılabilecek bir yerde, Kayseri-Pınarbaşı arasındaki Pazarören'de kuruluyordu. Sümer'in el-Kazvinî'den naklettiğine göre (1985: 14-15) Yabanlu Pazarı, her yıl baharın başında (Mayıs, en geç Haziran ayı içinde) açılıyor ve tam 40 gün açık kalıyordu. el-Kazvînî, "Bu pazara uzak yerlerden, doğu, batı, güney ve kuzeyden insanlar gelir. Tacirler bu pazara katılmak için pek büyük gayret sarfederler. Doğu tacirlerinin emtiasını Batılı tacirler alırlar. Batılılarınkini de Doğulu tacirler alırlar. Kuzeyden gelenlerin mallarını Güneyli tüccar ve Güneylilerinkini de Kuzeyliler alırlar" diye yazıyordu.

Rumeli'deki panayırlar ise Osmanlı Devleti'nin, Sanayi Devrimi'ne hazırlanan ve merkantilizm sürecini bitirmek üzere olan Avrupa ülkeleri ile bir nevi temas merkeziydi. Artan üretimlerinin bir sonucu olarak dış ticaretlerini büyütmek isteyen bu ülke tüccarları ile birlikte komşu ülke tüccarları da bu panayırlarda hem Osmanlı tüccarları hem de Osmanlı tüketicileriyle buluşuyordu. 17. ve 18. yüzyll öncesinde, yani Osmanlı klasik devrinde Rumeli'de panayırlar yaygın şekilde düzenleniyordu. Bunlar arasında Tor, Hersek'teki Milşova, Taşlıca'daki Prez, Usturumca, Alasonya, Çatalça, Hrupişta, Petriç, Yenişehir, Sıdraskapsa, İstorga, Karaferye, Katerina ve Çitroz sayılabilir. O dönemde bu panayırların içinde Tor ve Alasonya panayırları gibi uluslararası nitelikte olanlar da vardı. Moşkolor ve Berkofçe gibi bazı ulusal içerikteki panayırlara yabancı tüccarlar iştirak ederdi. Çünkü bunlar, geniş kapasite ve hacimli panayırlardı (Şen 1996: 10).

\section{Sergi-i Umûmî-i Osmanî}

Sultan Abdülmecid Dönemi, hızla sanayileşen Avrupa ülkelerini yakalama, teknolojik gelişmeyi ve fabrikalaşmayı Osmanlı Devleti'ne aktarma çabası içinde geçti. Bu amaçla dünyadaki gelişmelerin takibi ve Osmanlı'nın tarım ve sanayide elde ettiği ilerlemeyi göstermek için uluslararası sergilere katılım başladı. İlk katılım, 1851 yılında Sultan Abdülmecid Dönemi’nde gerçekleşirken, Türkler de panayır ve pazardan farklı bir şekilde tesis edilen gerçek anlamda bir fuar ile karşılaştılar 
ve bunun bir parçası oldular. 1851 Londra Sergisi ve sonrasındaki Paris ve II. Londra sergileriyle Osmanlı hükümeti yalnızca Avrupa ülkelerinin makineleşme ve teknolojik gelişmede ne kadar geliştiğini görüp buna göre tedbirler almaya girişmekle kalmadı, aynı zamanda ciddi anlamda bir sergi organizasyon kültürü de edindi. Osmanlı İmparatorluğu'nda panayır kültürünün değişimini ve sanayi üretimine paralel bir şekilde oluşan yeni fuarcılık anlayışına dönüşümü, 1863 Sergi-i Umûmîi Osmanî’nin simgelediği söylenebilir. O tarihe kadar Osmanlı'da düzenlenen panayır ve sergiler, dünyadaki sanayi ve ticaretin gelişimine paralel bir seyir izleyemediğinden geleneksel niteliklerden kurtulup modern anlamda bir gelişme sürecine girememişti. Oysa başta Avrupa ülkeleri olmak üzere ticaret ve sanayinin değişimi doğrultusunda sergi ve panayırlar da gelişerek, devrin teknik ilerlemesine uymuşlar ve yenilikler ile buluşların tanıtıldığı ortamlar hâline gelmişlerdi. Dolayısıyla sanayi devrimini gerçekleştiremeyen, sanayisini dönüştüremeyen ülkelerde ise, geçmişteki nitelikleriyle panayırlar varlıklarını devam ettiriyordu.

Sultanahmet Meydanı'nda 1863'te açılan Sergi-i Umûmî-i Osmanî, "Batı ölçüsünde ve zamanın sanayi gelişmelerini tanıtan ilk sergi" olmuştu. Avrupa ülkelerinin bu sergiye katılmasıyla uluslararası bir karakter kazanmıștı. Kuşkusuz, Batılı tarzdaki sergilerin Osmanlı'da yerleşmesine başlangıç teşkil eden 1863 Sergisi'nin teşkilinde 1851 Londra, 1855 Paris ve 1862 Londra dünya sergilerinin büyük payı vardı. Çünkü Hükümet'in teşvikiyle bu sergilere katılan Osmanlı tüccarları, benzer gelişmeleri kendi ülkelerinde görmek istemiş, bu da modern sergicilik fikri ile iktisadî uyanışın başlamasını temin etmişti (Şanda 1965a: 13).

"Memâlik-i Mahruse'de ilk defa açlan sergi" (Kadri Bey 1863: 430) olma vasfinı kazanan Sergi-i Umûmî-i Osmanî’yi düzenleme fikri ise Sultan Abdülaziz'e aitti. İstanbul'da bir sergi düzenlenmesini isteyen Sultan'ın bu düşüncesini, Sadrazam Keçecizade Fuad Paşa büyük bir şevkle desteklemişti. Çünkü Fuad Paşa, 1862 Londra Sergisi'ne sergi komiseri olarak katılan oğlu Nazım Bey vasıtasıyla fuarların faydasının ve sağladığı yeni imkânların farkındaydı (Giz 1968: 23). Kaldı ki, Londra Sergisi'nin ardından Osmanlıların böylesine kapsamlı bir sergi açması oldukça anlamlıydı ve uluslararası sergilerden ne denli etkilendiklerini göstermekteydi.

\section{Sergi-i Umûmî-i Osmanî̀nin Amacı}

Sergi-i Umûmî-i Osmanî, Bab-1 Âli’nin bir Osmanlı sanayisi oluşturma çabasının yeni bir ivme kazandığının somut göstergesiydi. Tanzimat'ın ilk yıllarında devletin öncülügüünde büyük fabrikalar kurarak sanayileşmeye çalışan Osmanlı İmparatorluğu, bu girişimden olumlu sonuçlar alamayınca, yeni bir anlayışa yöneldi. Bu anlayışın temelinde, özel sektörün teşvik edilmesi, tarıma dayalı da olsa milli bir sanayi oluşturma gayreti vardı. İşte bu gayret, yine özel sektör yatırımcılarının finansmanıyla hayata geçiyordu. Osmanlı hükümeti bu serginin hayata geçmesi için her türlü imkânı seferber ederek, milli sanayiyi destekleme kararlılığını açık bir şekilde ortaya koyuyordu.

1863'de İstanbul'da bir sergi düzenlenmesine karar verildiğinde bunun neden gerekli olduğu ve önemi Vilayet yöneticilerine anlatılmak istendi. Bu amaçla Vilayet merkezlerine gönderilen yazıda, "tarife hacet olmayacak" şekilde sergilerin mülkü (memleketi) imar etmede, zirai ürünler ve ma'mûlâtı çoğaltmada, sanayi ve meslekleri ilerletmedeki önemine işaret edilerek, bu ilerlemenin ancak onlara ait aletler ile ma'lûmâtın elde edilmesiyle hâsıl olduğu hatırlatıliyordu (BOA, A.MKT.MHM, 242/63). Yazıda "beher sene" vurgusu çok önemliydi. Gerek yurtdışındaki sergilerden, gerekse yurt içinde yapılması düşünülen sergiden bahsedilirken, "beher sene" yapıldığının veya "beher sene" yapılacağının altı çiziliyordu.

Avrupa'nın taraf taraf bazı mahallerinde beher sene mahsus ve umûm sergiler açlarak her yerin hiref ve sanayie dâir mahsûlât ve mamûlâtı enzâr-1 âleme" gösteriliyordu. Ayrıca ashâb-1 sanat ve marifetin kemâli, hüneri, mahâreti ve liyâkati bu sergiler sayesinde medh ve senâ ediliyor, "vükelâ-yı sanâyi' ve maârif bu tarik ile dahi yol (BOA, A.MKT.MHM, 242/63) alıyordu. 
Yazıda, “Allah'a hamdolsun ki, Memâlik-i Mahrûse, toprak mahsulleri ile en mümtâz bir dâire" denilerek, "halkımızın kabiliyet ve istidâdı ise mertebe-i kemâlde olarak ekser mahallerde birçok masnûât ve mamûlât var" şeklinde devam ediliyordu. Bu üstünlüklere rağmen "her nasılsa mülkümüzün ameliyât ve eşyası bazar-1 itibâra çıkarılamamakta ve destgâh-1 nisyânda kem-nâm olup kalmaktadır." Sultan Abdülaziz'in bunu kırmak ve memleketin umranı için ticareti geliştirmek için himmette bulunduğu belirtilen pusulada, "dahili imalatın dahi itibar mevkiine ulaşmasıyla sanayi ürünlerinin bir kat daha artması yüce bir istek" olarak niteleniyor ve sanayi ürünlerinin gelişmesinin ispatı olarak da "bu sene Londra'da küşâd olunan umûm sergilerine gönderilen eşyanın ekseri şâyân-1 takdir ve tahsîn" olması gösteriliyordu. Çünkü sergiye gönderilen memurlara bu yönde birçok ifadeler iletilmiş, ayrıca Avrupa gazetelerinde de benzer haberler görülmüştü. Avrupa görgüsünden sonra bir sergi geleneğinin oluşması, üretimin gelişimi üzerinde etkisinin somut olarak fark edilmesi, "an be an terakki”nin görülmesini sağlaması sebebiyle Osmanlı İmparatorluğu'nda da "mahsûlât ve ma'mûlât için beher sene Ramazan ayında Dersaâdet'te bir sergi açılması" hususu, gereğinin yapılması, mahallin tertip edilip hazırlanması için Sultan Abdülaziz'in emriyle Ticâret Nezâreti'ne havale edilmişti (BOA, A.MKT.MHM, 242/63).

1863 Sergisi’ni Avrupa'daki benzerlerinden ayıran en önemli özellikler, bir "muhasebe" ve “envanter" sergisi olma özelliği taşımasıydı. İmparatorluğun farklı eyaletlerinde üretilen mallar, bu malların kalite, çeşit ve fiyatları sergi sayesinde belirlenecekti. Bunun yanı sıra sergiyle hem üretimde karşılaşılan sorunlar belirlenecek, hem de sorumlu mevkidekilerin dikkati bu sorunlara çekilecekti. Ayrıca tüccarlar ile üreticiler sergi vesilesiyle bir araya gelerek tanışacaklardı (Önsoy 1988: 71).

Serginin amacı, Osmanlı Hükümeti tarafindan konuya ilişkin padişaha sunulan bir takrirde, "Bir süreden beri Avrupa ülkelerinde ticaret ve sanayinin geliştirilmesi amacıyla açılan sergilerin büyük faydaları görüldügünnden" şeklindeki ibarelerle ortaya konuyordu (Giz 1968: 24). Ama Osmanlı yönetici ve aydınlarının bu serginin düzenlenmesinden anladıkları maksat çok açıttı: "Memâlik-i Mahruse-i Şâhâne'de her türlü meslek ve sanayinin gelişip yaygınlaşması...." (Kadri Bey 1863: 337), gazeteler ise serginin açılış maksadını, “... Lakin asıl maksad Memâlik-i Mahruse-i Şahâne'nin mahsulât-1 araziyye ve ma'mûlât-1 sanayiisinin ne hâlde olduğu görülmekten ibarettir" diye açıklıyordu (Ruznâme-i Ceride-i Havadis 1863).

Bir başka açıklamada ise amaç, Osmanlı Devleti'nin bir zamanlar üretip de artık İstanbul'un yapımını unuttuğu eşyaları halka gösterip hatırlatmak diye ortaya konuyordu. Böylece Sergi-i Umûmî-i Osmanî ile "bir zamanlar neleri üretebildiğini hatırla ve gelecekte de neleri üretebileceğini düşün" temasının Osmanlı halkının zihnine nakşedilmesi hedefleniyordu. Bunun için de özellikle İstanbullu müteşebbislere güveniliyordu. $\mathrm{Bu}$ sebepten duyuruda “... Memâlik-i Şâhâne’de yapılmakta olduğu hâlde bir vakitten beri İstanbulca unutulan her nev'i eşyayı halka gösterip..." ifadeleri özellikle kullanılıyordu. Biliniyordu ki, Osmanlı üretici anlayışını yeniden keşfederse, "alıma-satıma yeniden revaç vermek" mümkün olacaktı. Bu özellikleriyle sergi, üretimde ve ticarette yeni bir heyecan oluşturacaktı. Dolayısıyla sergi, "hem büyük bir pazar ve hem de ehl-i san'ata gayet hayırlı bir imtihan meydanı" vazifesi görecekti. Burada üretici ve satıcıların rekabeti için, Osmanlı geleneğinden süzülerek Sanayi Devrimi'nin getirdiği yeni anlayışa adapte edilen en önemli tabir ise, rekabet ortamının karşılığ için kullanılan "hayırlı bir imtihan meydanı" ibaresiydi. Çünkü sergiyi düzenleyenler inanıyorlardı ki, bu hayırlı imtihan meydanında, "herkes akranından geri kalmamak için özenecek ve elden geldiği mertebe çalışacak" idi (Tasvir-i Efkar 30 Kasım 1862). ${ }^{1}$

Bu ifadelerden de anlaş1lıyordu ki, "İlk sergi, topraklarımız üzerinde yapılan ve fakat umumî rağbetten tedricen düşerek alıma ve satıma artık mevzu olmayan mevâddı

\footnotetext{
1 Tam metin şöyleydi: “İşbu sergi Memâlik-i Şâhâne'de yapilmakta olduğu hâlde bir vakitten beri İstanbul'ca unutulan her nevi eşyayı halka gösterip alıma satıma yeniden revaç vermek için hem bir büyük pazar ve hem de ehl-i san'ata gayet hayırlı bir imtihan meydanı olduğundan herkesin akranından geri kalmamak için özenip ve elden geldiği mertebe çalışıp göndereceği eşyanın gayet temiz ve rabıtalı olmasına sa'y ve gayret eylemesi lazımdır”.
} 
halkımıza tanıtarak, bunların tekrar revacını temin ve diğer taraftan da sanayi erbabını yeniliğe, icada doğru sevk ve teşvik eylemek fikir ve maksadıyla açılmıştır. Bu itibarla Türkiye'deki ilk sergiyi hem ilk sergi olarak hem de bilhassa birinci yerli mallar1 ve yerli sanayi sergisi olarak almak icap ve iktiza eder" (Nezihi 1931: 415).

Bu görüşü savunan bir yazara göre, 1863 Sergisi’nin “asıl maksadı, yerli sanatları teşvik ve himaye etmekti” ( Nezihi 1931: 415). Aslında bu düşünceyi doğrulayan çeşitli kanıtlar vardı. Öyle ki, bu belgeler ışığında 1863 Sergisi'nin Dersaâdet'te ticareti canlandırmayı hedeflediğini söylemek mümkündü. Sergiyi düzenleyenler, sergi bereketinin Dersaâdet esnafina ulaşması için gayret göstermişlerdi. Bu amaçla, sergi için ayrılan bütçeden eşya satın alınırken bu hususa özel önem verilmesi istenmişti. Sözgelimi Maliye Nezareti'ne gönderilen bir yazılda, Sergi-i Umûmîye konulacak her nevi emtia ve eşyanın fakir esnaf ve sanayi erbabından alınması tavsiye ediliyordu (BOA, A.MKT.MHM, 246/99). ${ }^{2}$

Sergi-i Umûmî-i Osmanî'de sergilenecek bazı ürünler sadece Dersaâdet'te değil, İmparatorluğun diğer eyaletlerinde de özel olarak imal ettirilmişti. Sergi komisyonu tarafindan belirlenen edevat ile eşya, esnafa sipariş edilmiş, vaktinde yetiştirilmesi için de "icâbının icrası", yani yakından takibi istenmişti (BOA, A.MKT.MHM, 251/21).

Sergi Komisyonu, Kütahya Kaymakamlı̆̆ı'ndan "oltarafdan dahi bazı eşya tedarik ve irsalinin (gönderiminin)" olacağını hatırlatarak, merkezden gönderilen pusulada yazılı toprak mamullerinin "dikkat ve nezaret-i mahsusa ile imal ettirilerek", diğer eşya ile birlikte kararlaştırılan vakitte yetiştirilmesi için lazım gelenin yapılmasını istiyordu. Bu da gösteriyordu ki, komisyon bazı bölgelerin görece uzmanlık alanlarının farkındaydı ve onlardan sergi için özel bazı ürünler istemişti. Hem ürünlerin niteliği açısından, hem de vaktinde gönderiminin sağlanması bakımından herhangi bir aksilikle karşılaşmak istenilmediğinden yetkililer sürekli yazı ile uyarılmıştı (BOA, A.MKT.MHM, 251/24).

Sergi hazırlığ1 noktasında devlet tarafindan yapılacak şeylerin icrasına geçilmiş, sergiye getirilecek bütün eşyanın Padişah'ın kontrolünden geçeceği düşüncesinden hareketle sergilenecek ürünlerin hemen şimdiden tedârik ve tertibine başlanmıştı. Sonuç olarak herkesin sergiyle ilgili üzerine düşeni yapması ve lazım gelen şeylerin Ramazan'ın girişinden evvele yetiştirilmesi için himmet buyurması Sultan Abdülaziz'den ayrıca talep ediliyordu (BOA, A.MKT.MHM, 242/63).

Sultan Abdülaziz’in büyük önem verdiği Sergi-i Umûmî-i Osmanî için ürünlerin tedarikinde gevşeklik ve ihmalkârlık gösteren valiler anında uyarılmıştı. Bunlardan biri de Halep valisiydi. Dersaâdet'e ulaşan haberlere göre "Sergi-i Umûmî içün Halep'den dahi taleb olunan eşyanın tertîb ve tedâriki" için "lâzım gelen teşebbüsâttan sarf-1 nazarla keyfiyetin Haleb ticâret meclisine bırakıldığ1 anlaşılmış" idi. Derhal valiye bir yazı gönderilerek, durum özetleniyor ve gerekli ehemmiyeti elbette takdir edip, icap eden tedbirleri alacağ1 açı olduğu belirtiliyor ama "serginin vakt-i küşâdı an be an tekarrub etmekte" denilerek nazikçe de uyarılıyordu (BOA, A.MKT. MHM, 250/24).

\section{Özel Sektörün İlk Fuar Yatırımı}

Bâb-1 Âli, serginin organizasyonunu gerçekleştirmek için bir "komisyon-1 mahsus" teşkil etti. Komisyon başkanlığına, dönemin Maliye Nazırı Prens Mustafa Fazıl Paşa getirilirken, üyeler de Hariciye Teşrifatçısı Kâmil Bey, Sadrazam Fuad Paşa'nın oğlu Meclis-i Vâlâ-1 Ahkâm-1 Adliye Üyesi Nazım Bey Efendi, Ticaret Nezareti Müsteşarı Server Efendi ile Azmi Beyefendi ve devlet ricalinden Agaton Efendi oldu (Ceride-i Havadis 26 Ocak 1863).

1863 Sergisi Türk fuarcılık tarihinde özel sektör tarafindan finanse edilip organizasyonu

\footnotetext{
${ }^{2} \mathrm{Bu}$ yazıda "...tertîb ve küşâdı muktezâ-yı İrâde-i Seniyyeden olan sergi-i umûmiyeye vaz‘ olunacak her nev` emtia ve eşyanın tedârik ve ihzârı içün ale’l-hesâb suretiyle ba'zı fukarâ-yı esnâf ve erbâb-1 sanayie verilmek üzere ta'vîzen ve ihtiyaten komisyon-1 mahsus cânibine bir yüz bin gurûşun i‘tâs1..." vurgulanıyordu.
} 
gerçekleştirilen çağdaş ilk sergi olma özelliğini taşıyordu. Her ne kadar düzenleme fikri Osmanlı Sultanı'na ait olsa da, Kırım Savaşı'yla birlikte girişilen aşırı borçlanmalar sebebiyle hazinenin kısıtlı imkânları sergi masraflarının devlet tarafindan karşılanmasını güçleştirmişti. Bunun üzerine başını Mısır Hidivliği varislerinden Mustafa Fazıl Paşa’nın çektiği, Mısırlı Sarraf Kevork, Eramian ve Oppenheim'den oluşan bir grup özel sektör yatırımcıs1, 1863 Sergisi Tertip Komitesi olarak sergi binasının yapımı dahil tüm maliyetleri üstlendiler (Önsoy 1988: 72). Kuşkusuz bunda Mustafa Fazıl Paşa'nın veraset yolu ile Mısır Hidivi olma hakkından vazgeçme karşılığında 4.5 milyon İngiliz altını tazminat almasının büyük etkisi vardı (Giz 1968: 23).

Fazıl Paşa bu parayla payitahtta etkinliğini artıracak faaliyetlere imza atıyor, İmparatorluk yönetiminde hızla yükselerek sırasıyla Maarif Nazırlığ1 ve Maliye Nazırlığ1 vazifelerine geliyordu. Bir anlamda Fazıl Paşa "su gibi para” harcıyordu. Kendi gücünü göstermek için sergi düşüncesinin çok önemli bir firsat olduğunun farkındaydı. Öncelikle Sergi Tertip Komitesi’nin başkanlığını üstlendi, daha sonra ise aralarında ecnebi tüccarların bulunduğu bir grupla devletin güçlük çektiği sergi binasının yapımı gibi işlerde aktif rol aldı. Bab-1 Âli de, serginin organizasyonu ve finansmanı gibi güçlüklerin sadece Mustafa Fazıl Paşa ile aşılabileceğinin farkındaydı. Bu hususu, Saray’a gönderdiği tezkirede "Her şeyden önce, işin süratle başarılması için, böyle şeylere hevesli ve yapıc1 bir zata havalesi gerektiğinden değer ve haysiyeti ve gösterdiği arzu bakımından bu görev Mustafa Paşa Hazretlerine verilmiştir" ibaresiyle ifade etmişti (Giz 1968: 24).

Mustafa Fazıl Paşa ise, sergi komisyonu başkanı sıfatıyla Sadaret Makamı'na yazdığı bir takrirde, serginin, memleketin servet ve bayındırlı̆̆ını artırma ve kamuoyunda yaratacağı faydalı ve politik etkiler düşünüldüğünde, her türlü masraftan kaçınılmaması gerektiğini hatırlatıyordu. Ancak, Hazine'nin imkânsızlıklarını göz önünde tutarak, 30 bin İngiliz lirası maliyetle en fazla yatırım kalemi olan sergi binasının inşası için bazı girişimlerde bulunduğunu açıklıyordu. Bu çerçevede Fazıl Paşa, bazı muteber tüccarlarla konuşulduğunu ve sergi binasının bir özel kumpanya tarafindan inşasına karar verildiğini bildiriyordu (Giz 1968: 24). Fazıl Paşa, sergi ana binasına ilaveten yapilan ve yabancı ülke ürünlerinin sergilendiği ilave pavyonun masraflarını ise bizzat kendisi karşılamıştı (Ergin 1995: 711).

\section{Sergi Mekânının Tespiti}

Sergi yeri olarak, Aksaray ve Sultanahmet'te farklı mekânlar gündeme geldi, ama sonunda hem merkezî konumu, hem de tarihî önemi nedeniyle geniş ve açık bir mekân olan At Meydanı'nda karar kılındı. Daha evvel Sultanahmet'te mevcut bazı binaların üzerinde durulmuş, ancak bunların ihtiyacı karşılamayacağına kanaat getirilmişti. Sergi binasının Osmanlı'nın yeni vizyonunu ortaya koyması için "tarz-1 cedid ve müstahsene" uygun yapılacağ1 bilhassa vurgulandı (Tasvir-i Efkar 30 Kasım 1862). Aslında bu "tarz-1 cedid” anlayışı Mustafa Fazıl Paşa’ya aitti. Paşa, 23 Cemaziyülevvel 1279 (16 Kasım1862) tarihinde Sadaret Makamı'na sunduğu takrirde, "ekspozisyon ittihaz edilecek yerin, her tarafa yakın ve tarz-1 cedid üzere (yani yeni tarzda) olması gerektiğinden" bahsetmişti (Giz 1968: 24). Bab-1 Âli de bu yaklaşımı aynen devam ettirmişti.

Binanın inşaatı Mustafa Fazıl Paşa, Mısırlı Sarraf Kevork, Eramian ve Oppenheim'den oluşan bir kumpanyaya ihale edildi (Önsoy 1988: 72). Tasarım ve uygulaması iki Fransız mimar olan Marie-Augustin-Antoine Bourgeois ile Leon Parvillee tarafindan gerçekleştirilen sergi binası 30 bin İngiliz lirasına mal oldu (Ergin 1995: 710). Sergi binası üç kapılı ve dikdörtgen şeklindeydi. Yaklaşık 2 bin 500 metrekarelik bir alana yayılan binanın ana cephesinin ortasında, binanin geri kalan kısmından daha yüksek, mazgallı çatı profilli ve kemerli kapılı, çıkıntılı bölüm bulunmaktaydı. Üç kemerli revakın üzerine "Sergi-i Umûmî-i Osmanî" yazılı bir kitabe konulmuştu. Bina tasarımının esası, daha önceki dünya sergilerinden alınmıştı. Böylece bölmelere ayrılabilen geniş bir salon oluşturulmuştu. Bununla birlikte özellikle cepheler İslam mimarisinden esinlenen renkler sebebiyle mimari tarz olarak neo-İslam bir üslûp taşıyordu (Çelik 2005: 150-151).

Sergi binasının iç kısmında tarım ürünlerinden dokumalara, sanayi ürünlerinden madenlere, 
deri eşyasından mobilyalara kadar uzanan geniş ürün yelpazesini sergilemek için 13 bölüm oluşturuldu. En geniş bölüm, Osmanlı'nın tarımdaki gücünü göstermek amacıyla, farklı bölgelerden gelen 212 buğday cinsine ayrıldı (Çelik 2005: 152).

\section{İlk Ulusal Fuar Nizamnamesi}

Sergi-i Umûmî-i Osmanî’nin işleyiş ve organizasyonuna ilişkin Avrupa'da düzenlenen sergilerle ilgili bilgilerden hiç de aşağı kalmayacak bir kapsamda hazırlanan sergi nizamnamesi, Ceride-i Havadis'in 5 Şaban 1279 tarihli 1128 numaralı sayısında yayımlandı. Ülkenin tüm "hâsılât1 arâziye ve sanaiyesinin" teşhir edileceği Sergi-i Umûmî-i Osmanî, Sultanahmet Meydanı'nda 1279 yılının Ramazan ayının başında açılıp Zilhicce ayının sonunda da kapanacaktı. Serginin başarılı bir şekilde gerçekleștirilmesi ve ürünlerin belirlenmesi amacıyla "bilcümle eyalet ve mutasarrıf ve kaymakamlıklarda ayr1 ayrı komiteler tayin olunacak" ve bu komitelerde mutasarrıf ve kaymakamların yanı sıra mahalli meclis üyeleri de yer alacaktı. Komitenin görevi, "kendisine getirilecek eşya ve emtiadan şâyân-1 kabul olup olmayanları tefrik ve temyiz etmek" olacaktı.

Sergiye eşya göndermek isteyenler, bulundukları dairenin komitesine müracaat ederek, "evvela eşyalarının mahsulât-1 Osmaniye ve dahiliyeden olduğunu ispat" edeceklerdi. Bir ürünün Osmanlı ürünü olup olmadığının ölçütü ise "Memâlik-i Mahruse'de hâsıl" olmasıydı. Osmanlı topraklarında üretilen bir ürün, üreticisi yabancı ülke tebaasından olsa bile yerli mal sayılacaktı. Bu husus nizamname dışında gazetelerde yayınlanan haber ve duyurularda da özenle vurgulandı ve yabancı ülke teb'ası olan kişilerin Osmanlı ülkesinde bulunan fabrikalarının ürünleri ile yine burada esnaflık eden yabancıların mamulâtının yerli ürün/mamulât-1 dâhiliye sayılarak, sahiplerinin müracaat etmeleri hâlinde memnuniyetle kabul edileceği ilan edildi (Tasvir-i Efkar 30 Kasım 1862). Yurtdışından getirilen ve istisnai olarak sergiye kabul edilecek "mamulât-1 ecnebiyeden edevat, ziraat ve saire misillu makineler ise hangi memleket ürünü ise o yerde bulunan Devlet-i Aliyye hazerâtı ve şehbenderleri tarafindan tasdik edilecekti." Ayrıca her türlü eşya ve mahsulât için bağlı olduğu komitenin ruhsatıyla gönderildiğini gösteren bir adet pusula olacaktı. Yine komiteler, Şaban ayının başlangıcında "dairelerinde bulunan eşya sahiplerinin isim ve şöhret ve mahall-i ikametlerini ve gönderilen eşyanın cins, miktar ve fiyatıyla bunlara dair mülahazalarını açıklayan birer kıta deftere tanzim edip" göndereceklerdi (Ceride-i Havadis 26 Ocak 1863).

Sergi Nizamnamesi, sergiye kabul edilecek ürünlerin çeşit ve vasıflarını da açıklı̆ga kavuşturuyordu. Buna göre Osmanlı Devleti'nde üretilen "bilcümle emtia, sanayi, tarım ve maden ürünleri ile alet ve makinelerden her ne konulur ise kabul" olunurken, yabanci ülkelerden "yalnız çiftçilik ve bahçıvanlığa müteallik ve dükkân ve evlerde istimal olunabilen alet ve edevât" kabul edilecekti. Sanat ve ticarete faydası olmayan eşyalar ile "az vakitte bozulabilen" çiçek, taze meyve, sebze ve canlı hayvan gibi tartışmalı eşya, sergiye alınmayacaktı. Sergiye gönderilen emtia ve eşyanın hem meclis-i hiber (bilirkişi heyeti) tarafindan muayene ve seçiminde, hem de sergilenecek mahallin seçim ve tanziminde kolaylık sağlamak için ürünler 13 kategoriye ayrılmıştı. Bu kategoriler şöyleydi:

- Tarım, hayvancilik ve orman ürünleri

- Un, şeker, şeker mamulleri, gül ve çiçek suyu, sirke ve meşrubat

- Ham ve külçe maden numuneleri, madencilikle ilgili alet ve makine, mermer, alç1 taşları, inşaat malzemesi, odun ve maden kömürü

- Sanayi ve mesleklerde kullanılan alet ve makine, saat, çilingir, anahtar, kazancı, bakırc1 ve dökmeci işleri, ateşli silah, kurşun, gülle ve araba

- Altın ve gümüş mamulleri, her türlü mücevherat, gümüş takımları, pirinç ve boyalı eşya

- Koza, ham ve işlenmiş ipek, pamuk, yün ve tiftik

- İpek, pamuk, yün ve tiftik ve kenevirden yapılmış kumaş, bez, basma, şal, çorap, çuha, aba, fes, fanila, çarşaflık ile iplik ve çeşitli ibrişim 
- Toprak ve cam mamulleri, 1triyat, sabun, tespih, çam sakızı, neft yağı, bitkisel yağlar, boya ve mum

- İşlenmiş deri ve deri mamulleri, eyer, başlık, koşum, çul, çuval gibi saraciye eşyası, ayakkabı ve kürk

- Elbise, türlü giyim eşyaları, el işleri, havlu ve sofra takımları

- Sandalye, masa, kütüphane gibi ağaç işleri, müzik aletleri, keçe, hal, kilim ve hasır

- İnşaat model ve resimleri, kara kalem ve boyalı resimler, düz ve kabartmalı haritalar,taşçı ve oymacı mamulleri

- Matbaacılıkla ilgili harfler ile taş üzerine basılı kitap, risale, döğme harfler ve litoğrafya ve fotoğrafya işleri, tezgâh ve makineleri; mücellit ve hakkak ürünleri (Ceride-i Havadis 26 Ocak 1863 [Fasl-1 Sâni]).

Nizamname hükümleri, "sergiye konacak eşya"nın Şaban'ın on beşinden evvel sergi mahalline ulaştırılmasını karara bağlıyordu. Bunun için taşradaki komiteler kendi dairelerindeki emtia ve eşyayı toptan olarak bir kerede göndermekle yükümlüydüler. Komiteler, gönderdikleri eşya ile beraber "eşya sahibinin isim, şöhret, ikamet mahalli, eşyaların cinsi, adedi, miktarı ile fiyatını; çiftlik ve kârhanelerin cesamet ve ehemmiyetini; üretimde kullanılan alet ve makineler ile usul-1 sanayisini, istihdam edilen amele sayısını, üretim için kullanılan hammaddenin (mevadd-1 asliyenin) nevi ve miktarı ile ürünlerin kemmiyet ve miktarını açıklayan” bir defter de gönderecektiler. Eşyaların nakliye masrafları ile onları getiren memurların harcırahları mensup oldukları eyalet ve livaların mal sandıkları karşılanacaktı. Görevli memurların Dersaâdet'te kalacakları her gün için kendilerine Osmanlı Devleti tarafindan yevmiye ödenecekti (Kadri Bey 1863: 342). Sandiklarin üzerinde eşyanın hangi mahalden geldiğini, nevini ve cinsini işaret eden pusulalar bulunacaktı. Eşya sahipleri serginin açık olduğu vakitlerde eşyalarının başında bulunabilir, ya da komisyonun kabul edeceği bir vekil tayin edebilirlerdi. Eşyaların sergi mahalline konulması için lüzum görülen dolap ve sairenin inşa masrafları da devlete aitti. Sergilenecek tüm eşya hakkında izah ve ma'lûmât verecek bir defter de sergi komisyonu tarafindan basilıp yayınlanacaktı (Ceride-i Havadis 26 Ocak 1863 [Fasl-1 Salis]).

1863 Sergisi’nde ürünler teşhir edilmekle kalmadı, aynı zamanda satışa da sunuldu. İstanbul dışından gelen ürünlerin bedellerinin sahiplerine ulaştırılması Hükümet marifetiyle gerçekleştiriliyordu ve Hükümet'in teminatı altındayd1 (Ceride-i Havadis 26 Ocak 1863 Fasl-1 Hâmis, Otuz Beşinci Bend). Sadece satılan ürünlerin bedelleri değil, sergiye gönderilip de satılamayan ürünlerin bedelleri de sahipleri tarafından belirlenen miktar üzerinden Hazine tarafindan eşyayı getiren görevliler vasıtasıly sahiplerine ödenecekti. Ayrıca geri gönderilmeye değmeyecek, bir anlamda gönderim masrafı ederinden daha fazla olan "ufak tefek şeyler" de Hükümet tarafindan satın alınacaktı (Tasvir-i Efkar 30 Kasım 1862).

Sergiyi düzenleyenler, 1863 Sergisi’ni sadece ürün teşhir edilen Avrupaî bir fuar olarak görmüyorlardı. Onlara göre, gerek eyaletlerden, gerekse Dersaâdet'ten eşya gönderen, numune-i mamulât arz eden her sanat ve meslek sahibi için "bu sergi bir büyük imtihan meydanı" idi. Dolayısıyla "sanatça akranına faik olan ve resanet (sağlamlık) ve nefasette (güzellikte) mamulâtın yekdiğere nispetle derecesi" sanat ve mamulât ashabından oluşan bir meclis-i ehl-i hibre (jüri) tarafindan tayin edilecekti. Bu amaçla bir jüri heyeti tesis edilecekti. Mustafa Fazıl Paşa'nın başkanlığında toplanan komisyon, ilk toplantılarını Paşa'nın konağında yapmıştı. Ancak daha sonraki toplantılara Maarif Nezareti'nin Ticarethane'deki dairesinde her hafta salı günleri devam edildi (Tasvir-i Efkar 30 Kasım 1862).

Sergiye katılan ürünler, heyet-i ehl-i hibre (jüri) tarafından değerlendirilerek, nitelikli olanlar ödüllendirildi. Sergiye konulacak ürünler 13 kategoride değerlendirildiği için, bu 13 kategoride 13 jüri heyeti oluşturuldu. Nizamnamenin 43. bendi hükmünce "Ehl-i hibre komisyonları birinci ve 
üçüncü ve yedinci ve onuncu ve on birinci sınıflar için yedişer; ikinci, dördüncü, beşinci, altınc1, sekizinci, dokuzuncu, on ikinci ve on üçüncü sınıflar için beşer nefer azadan ibaret" olacaktı (Ceride-i Havadis 26 Ocak 1863 [Fasl-1 Sâdis, Kırk Üçüncü Bend]). Serginin açılmasıyla birlikte komisyon hemen eşyaları incelemeye başlayacak ve "müddet-i kalile zarfinda" görevini tamamlayacaktı. Eşya sahiplerine 3 derecede mükâfaat verilecekti; birinciye mecidiye nişan-1 hümâyûn, ikinciye gümüss madalya, üçüncüye ise pirinç madalya verilecekti. Mecidiye nişanına, “yalnızca sanatça pek büyük faydalı bir şey keşf ve buluş yapan veya ürününü san'at-1 nefaset ve resanetçe henüz vasıl olunmayan bir dereceye isal eyleyenler nail olacaktı." Nişan ile birlikte ayrıca özel bir şahadetname de verilecekti (Ceride-i Havadis 26 Ocak 1863 [Fasl-1 Sâbi]).

\section{İlk Türk Sergi Dizaynı}

Sergi-i Umûmî-i Osmanînin iç tasarımı, standların oluşturulması ve ürünlerin usulüne uygun yerleştirilmesi için de "işten anlar bir mütehassısa" ihtiyaç duyuldu. Bu amaçla Mösyö Valer isminde bir Fransız bulundu. Mösyö Valer, sergide teşhir olunacak ziraat ve sanayi ürünlerinin estetik derecelerini "keşf ve tahkike memur" kılınmıştı. Bütün stand ve ürün dizaynından sorumluydu. Sergi binası Ramazan başlamadan birkaç gün önceden teslim edildiğinden eşyaların düzenlenmesi ve konulması ancak açılış günü sabaha karşı bitirilmişti (Nezihi 1931: 416).

Ortaya çıkan esere bakılınca, oldukça ustalıklı ve incelikli bir çalışma ortaya koyduğu söylenebilir. Osmanlı'nın uluslararası çapta ve modern sergi anlayışıyla gerçekleştirdiği bu ilk fuar organizasyonu, ziyaretçiler tarafından çok beğenildi. Öyle ki, serginin "hüsn-i tertip ve intizamı doğrusu derece-i me'mulenin mafevkında bulunduğundan cümlenin mazhar-1 takdir ve tahsini”" olmuştu. Sergi binasına girer girmez tüm bakanlar, konulan eşyanın nefaset ve intizamını düşünülenden birkaç kat ziyade buluyor ve sergileme tarzının hüsn-i tesiri altında kalıyordu (Münif Bey 1279: 362).

Hem sergi binası hem de serginin iç tasarımı ve ürün yerleştirme nasıl yapılmıştı da ziyaretçileri bu denli etkilemişti? Sergi binası 7 bin arşın arsa üzerine dikdörtgen biçimde inşa edilmişti. Ortasında yine dikdörtgen şeklinde 2.300 arşın genişliğinde bir bahçe olup bunun da ortasinda bir mermer fiskiye bulunuyordu. 1851 Londra Sergisi'nin ana binasi olan ve o tarihten itibaren tüm mimariyi etkilemiş olan Kristal Palas'ın etkisi 1863 Sergi binasında da görülüyordu. Çünkü Osmanlı sergi binasının orta bahçesinin ve diğer bazı yerlerinin tavanı cam ile örtülmüştü. Ayrıca binanın üç cephesinde halkın giriş ve çıkışı için üç büyük kapısı vardı (Münif Bey 1279: 363).

Serginin dahilinde duvara dayalı bir şekilde 3,5 arşın yükseklik ve genişliğinde camlı dolaplar bulunuyordu. Bu tarz dolaplardan çeşitli hacim ve biçimde 50'den fazla orta dolap da vardı. Eşyalar cinsleri itibariyle ayrılarak bu dolaplara konulup yerleştirilmişti. Boş kalan bazı duvarlar ile bahçenin etrafinda ve diğer bazı yerlerdeki direkler ise rengârenk kaliçe ve keçeler ile kapatılıp süslenmişti. Hububat, un ve sıvı şeklinde toprak ve sınaî ürünleri billur şişelere konulmuş, üç kademeli olarak bahçe duvarlarının etrafına dizilmişti. Burada 10 bini aşkın çeşit ürün sergilenmiş, hepsinin "cins, miktar, fiyat, üreticisinin isim ve şöhreti gibi faydalı bilgileri”" içeren mufassal bir defter de tutulmuştu (Münif Bey 1279: 363-364).

$\mathrm{Bu}$ arada sergi komitesi, gerek İstanbul'dan gerekse eyaletlerden başkente gelen eşyaları, At Meydanı'na bakan Harbiye ambarları dahilinde münasip bir yerde topluyordu. Komisyon görevlileri, bu ambarlarda ilk çalısmalarını yürütüyor, ürün seçimlerini yapıyor, ziraat ve sınâ̂ ürünlerini kategorilere ayırıyor ve daha sonra da sergi alanına gönderiyordu (Kadri Bey 1863: 338).

\section{Güvenliğin Sağlanması ve Yangın Önlemlerinin Alınması}

Sergi-i Umûmî-i Osmanî için güvenlik tedbirleri alınması ihmal edilmemişti. Hem sergi alanının bulunduğu Sultanahmet'e civarda bulunan polislerden kaydırma yapılıyor, hem de sergi alanı için özel bir itfaiye gücü görevlendiriliyordu. Sözgelimi serginin güvenlik hizmetlerinde kullanılmak üzere Kanlıca'daki Binbaşı İzzet Ağa ile 10 nefer polis buraya tayin edilmişti. Aynı 
şekilde tulumbacılardan 50 nefer ile 5 aded tulumbacı dahi sergide vazifelendirilmiş, tulumbacılar için serginin görsel bütünlügüule uyuşan özel elbiseler diktirilmişti. Öyle ki, "bunlar içün lâzım gelen elbisenin vakt-i mukarrerinde (belirtilen sürede) yetişmek üzere hemen i'mâl ettirilmesi husûsu" için ilgililer dikkatli ve hızlı hareket noktasında ikaz edilmişlerdi. Serginin güvenliği ve yangın önlemlerinin alınması konularında zabtiye müşiri gerekenleri yapmaktan sorumlu tutulmuştu (BOA, A.MKT.MHM, 251/10).

1863 Sergisi, şehrin imarına ve altyapı hizmetlerinin düzenlenmesine katkıda bulunmuştu. Sözgelimi Sergi-i Osmânî sebebiyle Dersaâdet haritası üzerinde, sergi çevresinde bulunan yollar işaretlenerek, bu yolların ve kaldırımların düzenlenmesi ve tanzimi sağlanmıştı (BOA, A.MKT.MHM, 252/58). Bir başka belgeye göre de Bahçekapısı'ndan Ayasofya Caddesi'yle Sultanahmed Meydanı'na kadar olan yol kaldırımlarını teftiş eden yetkililer, buradaki kaldırımların tamir edilip aç1lıştan evvel bitirilmesini istemişlerdi (BOA, A.MKT.MHM, 251/10).

\section{Serginin Aç1lış1}

Tüm bu hazırlıklardan sonra Osmanlı İmparatorluğu'nun merkezî hükümet tarafindan düzenlenen ilk uluslararası standartlardaki sergisi, 27 Şubat 1863 yllında Sultanahmet'teki At Meydanı'nda açıldı. Sergi-i Umûmî-i Osmanî adıyla anılan fuarın açılışı, kutsal bir vakit olması sebebiyle Ramazan'ın 9. gününe tesadüf eden Cuma günü yapılmıştı (Selahaddin Bey 2008: 27-29).

Aslında sergi açılışının, 1279 yllının Ramazan ayının ilk günü yapılması planlıyordu (Ergin 1995: 710). Ancak inşaatın zamanında bitirilmesine rağmen sergilenecek mallar, bazı eyaletlerden İstanbul'a şiddetli kış sebebiyle zamanında ulaşamadı. Vaktinde gelen eşyalar ise sergideki yerlerine konulamadı (Münif Bey 1279: 362; bknz. Havadis'ten aktaran Gültekin 1982: 24). Çünkü sergi binasının bazı bölümlerinin boyası henüz kurumamıştı (Tercüman-1 Ahval 1863). Sergi, 9 günlük bir gecikmeyle 27 Şubat 1863'te, Ramazan ayının 9. gününe rastlayan Cuma günü açıldı. Sultan Abdülaziz, Sultanahmet Camii'nde tertip olunan selamlık töreninden sonra sergi binasına gelerek açılışı yaptı (Münif Bey 1279: 362). ${ }^{3}$ Yanında Mısır Hidivi İsmail Paşa, Sadrazam Yusuf Kâmil Paşa, Hariciye Nazırı Âli Paşa, Serasker Fuad Paşa ve diğer vekiller de hazır bulundu (Ergin 1995: 710).

İlk gün 4 saat boyunca sergiyi gezen Sultan, sergiden o kadar memnun kaldı ki, ertesi gün de sergiye gelerek, pavyonları tek tek ziyaret etti. Bu memnuniyetin bir sonucu olarak, ziyaretçilerin görmesi için, Hazine-i Hümâyûn'da muhafaza edilen kıymetli mücevheratın teşhir edilmesini istedi (Ergin 1995: 710). Ramazan'ın 21. günü Valide Pertevniyal Sultan da Şehzade Yusuf İzzettin Efendi ve Saray'dan bir grupla birlikte sergiyi ziyarete geldi (Giz 1968: 35). Ramazan'ın sonuna kadar geçen 21 gün içinde ise sergiyi kadın ve erkek toplam 54 bin kişi ziyaret etmişti (Münif Bey 1279: 367). Şevval'ın 16'sında, yani açılıştan 37 gün sonra ise sergiyi temaşa edenlerin sayısının resmi defterlere 80 bin olarak işlendiği açıklanıyordu (Tercüman-1 Ahval 1863/315; Tasvir-i Efkar 1863/364).

Fuar iki binadan meydana geliyordu. Girişte yer alan ana fuar binasında sadece Osmanlı Devleti'nin muhtelif eyalet ve şehirlerinden gelen ürünler sergileniyordu. Ancak yabancı ülkelerden gelen ürünler için, ana fuar binasının arka tarafina bir ek bina inşa edildi. Makinelerin kolayca içeri sokulabilmesi için düzayak olarak yapılan ek bina, gösterişsiz yapısıyla Dikilitaş’tan At Meydanı'ndaki Hipodrom'a kadar uzanarak, Serpentine kolonunu tamamen çevreliyordu (Salahaddin Bey 2008: 29).

Sergi-i Umûmî-i Osmanî, 27 Temmuz'dan 1 Ağustos 1863 tarihine kadar tam 5 ay açı kald. Bu süre zarfinda ziyaretçilerden 450 bin kuruş gelir elde edildi (Salahaddin Bey 2008: 29). Sadece bu meblağ bile, fuarı ziyaret etmek için İstanbul ve diğer illerden gelenler ile yabanciların

\footnotetext{
${ }^{3}$ Bugüne kadar kaynaklar (Bkz.: Tercüman-1 Ahval, Numara 304, 11 Ramazan 1279), Sultan Abdülaziz'in Ayasofya'da Cuma namazını kıldıktan sonra açılışı yaptığını yazıyordu. Ancak Münif Bey'in aktardığı bilgi, ilk kez Cuma selamlığının Sultanahmet Camii'nde düzenlendiğini, sonrasında da Padişah ve maiyetindekilerin hemen yanı başındaki sergi alanına gelip açılışı yaptıklarını yazıyor.
} 
sergiye ne büyük bir ilgi gösterdiklerini ortaya koyuyordu.

Sergi cuma, pazar, pazartesi, salı, perşembe günleri erkeklerin; çarşamba ve cumartesi günleri ise kadınların ziyaretlerine açıktı. Ziyaretçilerden cuma ve cumartesi 6 kuruş, diğer günler ise 3 kuruş duhuliye, giriş ücreti alınacaktı. Kadınların ziyaretçi olduğu günlerde, sergi alanında eşya sahipleri dişında kimse bulunmayacaktı (Ceride-i Havadis 26 Ocak 1863)Kadınların ziyaret edeceği günlerle ilgili kurala ilk hafta uyulmadı. 9 Şubat Cuma günü açılan sergi, kadınların ziyaret günü olan cumartesi günü kadınlar yerine "seyr ve temaşaya gelen bazı zevât-1 kiram" ile "lütfen ve tenezzülen sergiyi teşrif” eden Sultan Abdülaziz’i ağırladı (Ceride-i Havadis, 2 Mart 1863). Takip eden çarşamba günü de kadınlar yerine erkek ziyaretçiler sergiye alındı, ancak sonraki cumartesi gününden itibaren kadınların ziyaret günlerine harfiyen riayet edildi (Tercüman-1 Ahval 2 Mart 1863).

Erkeklere mahsus günlerde ortalama 2 bin, kadınlara mahsus günlerde ise ortalama 6 bin ziyaretçi sergiyi gezdi. Bunun üzerine kadınlara mahsus gün sayısı, ikiden üçe çıkarıldı (Giz 1968: 25). Yabancı ürünlerin sergilendiği ek bölüme kadınlardan fazla rağbet olmadığından onlar için ayrı bir gün tahsis edilmedi. Kadın ve erkekler bu mahalli karışı olarak ziyaret edebiliyorlardı. Zaten günlük ziyaretçi sayısı birkaç yüzü zor buluyordu (Münif Bey 1279: 408). Sergiye giriş ücreti olarak cuma ve cumartesi 6 kuruş, diğer günler 3 kuruş, çocuk ve askerlerden ise 1,5 kuruş alınıyordu (Ceride-i Havadis 26 Ocak 1863). Yabancı devletlerden gelen alet ve edevatların bulunduğu ek bina ise 2 kuruşa ziyaret edilebiliyordu (Münif Bey 1279a: 408). Daha sonraları sergiyi daha fazla kişinin ziyaret etmesini sağlamak için giriş ücretleri ucuzlatıldı (Tercüman-1 Ahval 30 Mart 1863). Gerekçe olarak da "serginin açılış maksad1, sanayinin ilerlemesi, sergide teşhir edilen eşyaların herkes tarafindan görülmesi" gösterildi (Ceride-i Havadis 11 Mayıs 1863).

Değerlendirmeler sonucu Halep eşyasını teşhire memur Şeyh Mustafa Efendi, Beyrut eşyasını teşhire memur Abdülkadir Efendi, Şam eşyasını teşhire memur Abdülkadir Efendi, Diyarbekir eşyasını teşhire memur Abraham, Bağdat eşyasını teşhire memur İskender, Yanya eşyasını teşhire memur Kosto Piço, Halepli iş adamlarından Anton Zati ve M. Donato, Dersaâdet eşyasını teşhire memur Dr. Filori beşinci mecidiye nişanına lâyık görüldü. Yabancı firmalardan ise Ransomes, Garret ve Fils, Ganneron ile mühendis ve teknikerler de muhtelif mecidiye nişanlarıyla taltif edildi (Önsoy 1983: 233). Ayrıca Sergi-i Osmânî hakkında sadece Osmanlı yazar ve gazetecileri köşe yazısı, haber ve kitap yazmamışlardı. Aynı zamanda yabancılar da bu sergi hakkında çeşitli yazılar kaleme almışlardı. Bunlardan biri olan Mösyö Lui de Sergi-i Osmanî hakkında bir kitap telif etmiş, bu hizmetinden dolayı da kendisine "beşinci mertebeden bir kıt'a mecidiyye nişân-1 zîşânî" verilmesi uygun görülmüştü (BOA, A.MKT.MHM, 329/21).

\section{Sergide Teşhir Edilen Ürünler}

Sergide İmparatorluğun çeşitli bölgelerinden gönderilmiş 10 bin kalemin üzerinde ürün teşhir edildi. Sergilenen ürünlerin zenginliği, bir övünç kaynağı oldu. Sergideki en geniş mekân1, İmparatorluğun hemen hemen her tarafindan gönderilmiş olan tarım ürünleri almaktaydı. Ürünlerin fiyatları dünya piyasalarından daha ucuzdu. Sergide yer alan tarım ürünlerinin başlıcaları şunlardı: Buğday, çavdar, yulaf, arpa, mısır, pirinç, tütün, pamuk, keten ve kenevir, yün, ipek böcekçiliği. Orman ürünleri de zengin ağaç çeşitleriyle sergideki yerini almışt: Meşe, çam, ceviz, şimşir, selvi, söğüt, kavak, şimşir, kayın, kara ağaç, akça ağaç, kızıl ağaç, yabani fındık, ardıç ağacı (Önsoy 1983: 210-213).

Maden pavyonunda ise İmparatorluğun dört bir köşesinden gelen maden numuneleri bulunuyordu. Kurşun, gümüş, altın, şap, demir, bakır, grafit, cıva, taş kömürü, göl, kaya ve deniz tuzları, kükürt, arsenik sülfür, zırnık, kireç, granit, alçı, lüle taşı, piroksen, zebercet, şeffaf oksit, bazalt, pirit, demir sülfür, mermer, sarı ve kırmızı mermer, çeşitli yumuşak ve sert çeşitli taşlar. Ayrıca burada kaydetmek gerekir ki, bu mermerlerden yapılmıs masa, konsol, ocak ve vazo gibi mermer eşyalar da teşhir edilmişti (Önsoy 1983: 218-220). 
Dokumacıllk bölümünde ise genel hatlarıyla ifade etmek gerekirse, yünlü ve ipekli kumaşlar, masa örtüleri, hamam takımları, el havluları, yatak takımları, perdeler, ipekli peştamal, kadifeler, ipek kravat ve çoraplar, çok sayıda yünlü ve pamuklu dokumalar, başörtüleri ve çoraplar, yazmalar, renkli basma ve pazen, iç çamaşırları, halı ve kilim ve seccadeler yer alıyordu. Ayrıca pavyonda birçok eyaletten gelen sığır derisi, meșin ve sahtiyan gibi ürünlerde yer alıyordu. Koyun ve keçi derisi numuneleri ile bunlardan yapılan ayakkab1, potin ve terlikler de sergide teşhir ediliyordu. Yine tabanca, bıçak k1lıfları, keman yayları, eyer ve at koşumları, bel kemerleri ve palaskalar, terlik, bavul, para cüzdanları, deri elbiseler de bulunuyordu (Önsoy 1983: 221-227). Özellikle Beyoğlu Kışlası Kundura Atölyesi'nde yapılan askeri potinler, Sultan Abdülaziz başta olmak üzere birçok ziyaretçinin takdirini toplamıştı.

Dokumacılık bölümünde teşhir edilen ürünlerin büyük bölümü İzmit Çuha Fabrikası (Basmahane) ve Feshane'de imal edilen ürünlerden oluşuyordu. Basmahane'den 500 kalem dokuma ürünü gelirken, bunun 100 kadarı gömleklik ve kadın elbisesi kumaşlarından oluşuyordu. Yine 60 civarında emprime çeşidi vardı ki, masa örtüsü, perde ve elbiselik olarak kullanılıyordu. Diğer numuneler arasında ise yünlü ve pamuklu çoraplar, eldivenler ile ağartılmamış pamuktan mamul Amerikan denilen dokumalar mevcuttu. Ne var ki, Basmahane ürünleri aynı kalitedeki Fransız dokumalarından yüzde 15 nispetinde daha pahalıydı. Feshane'den ise 300 civarında eşya gelmişti. Bu eşyaların çoğu ince askerî kumaşlardı, ordu elbiseleri için kullanılan kırmızı, siyah veya renkli dokumalar, örtüler, kuşaklar ve çadır bezleri ile feslerdi. Feshane'de ağırlıkla fes üretilmesine rağmen ihtiyacı karşılamaktan uzaktı. Bu nedenle Tunus, Fransa ve Alman ülkelerinden 500-600 bin civarında fes ithal ediliyor, karşıllğında da 9 milyon kuruş ödeniyordu (Önsoy 1988: 83).

Sergiye Lübnan malı tekstil ürünleri ile Halep, Şam, Diyarbakır'dan da dokuma mamulleri geliyordu. Kuşkusuz dokumacılık denilince Bursa akla gelirdi ve sergiye Bursa'dan da 300 kalemi aşkın mal gelmişti. Daha çok ev tekstili ağırlıklı bu ürünler arasında hamam takımları, el havluları, yatak takımları, masa örtüleri, perdeler, ipekli peştamal, ipek ve pamuk karışımı entarilik kumaşlar, elbise ve mobilyalık kadifeler, ağır ipekli dokumalar, atlas kumaşlar, ipekten yapılma şark tipi elbiselik kumaşlar, kravat ve çoraplar vardı. Bursa'dan Salih Efendi’nin gönderdiği 200 parça eşyanın içinde yazlık elbise ile gömleklik çizgili ve kareli ipekli dokumaların bulunması da ilginçti. Bursa özel sektörünün temsilcisi Salih Efendi, "sık dokunmuş ve Avrupa zevkine göre desenlenmiş kumaşlar" da göndermişti (Önsoy 1988: 85). Bu durum, çok açık biçimde, Bursalı tekstilcilerin halkta oluşan Avrupaî beğeniyi yakından takip ederek ona göre üretimlerini şekillendirdiklerini ortaya koyuyordu.

1863 Sergisi öncesindeki gelişmelere bakarak, Bursa’nın dokumacılıkta Avrupa ile yarıştı̆̆1 söylenebilir. Daha 1850'lerde Bursa'da buhar ve su gücüyle çalsşan tıpkı Avrupa'daki benzerleri gibi kurulmuş modern ipek fabrikalarından 14 tane vardı. Bursa'ya yakın Mudanya, Bilecik ve Osmaneli'nde de birer ikişer imalathane yer alıyordu. Bu bölgedeki işyerlerinde $55.000 \mathrm{~kg}$ ipek işleniyordu. Çoğunluğu Ermeni ve Rumlardan oluşan bin 700 işçi çalışıyordu. Ne var ki, bu fabrikaların sevk ve idaresinden sorumlu kişiler ve mühendisler Fransa ve Avusturya'dan getirilmişti (Önsoy 1988: 84-90). Dolayısıyla yerli bir üretim geleneği ve anlayışı oluşması engellenmişti.

1863 Sergisi'ne gönderilen ve beğeni toplayan ürünlerle ilgili belirtmek gerekir ki, çeşitli eyaletler ve sancaklar ile İstanbul'dan birçok özel sektör üreticisi ile zanaatkâr ustalar görenlerin hayranlıklarını ifade ettikleri ürünleriyle sergiye katılmıslardı. Binlerce ürün arasında Amasya'dan Şerife Hatun ipekten yapılmış düz, desenli ve sırmalı kadın kumaşları; Konyalı Hacı Mustafa yünlü ve pamuklu dokumalar ile başörtüsü ve çorapları; Bursa'dan İbrahim Usta ve Hacı Mustafa ipek elbiselik kumaşları, ipek kravatları, çorapları ile elbiselik ve mobilyalık kadifeleri; Diyarbakır'dan Ali Efendi kırmızı ipekleri, yine Diyarbakır'dan Mustafa ve Abdullah efendiler sarı ve kırmızı pamuklu kumaşları; İzmir'den Hacı Halil Efendi çeşitli halı ve kilimleri ve Hacı Mikail gümüş işlemeleriyle dikkat çekmişti (Önsoy 1988: 84-90). 
Bu durum şu gerçeği ortaya koyuyordu: Geleneksel üretimin bir parçası olarak çalışmalarını sürdüren bu insanlar, geniş çaplı olmayan ama kaliteli ve görenlerin takdirlerini kazanan ürünleri ile varlıklarını sürdürmeyi başarmışlardı. Üstelik bu ürünlerin fiyatları da fabrikasyon üretim sonucu elde edilen ürünlerden kat be kat daha pahalı değildi. Birçoğu daha ucuzdu, bir kısmı da yüzde 1520 oranında daha pahalıydı. Peki, eksiği çekilen durum neydi? Eksik olan, geleneksel üretim anlayışının devamı olan bu ara elemanlar, bu usta ve küçük işletme yöneticileri modern üretim anlayışının bir parçası hâline getirilememişti. Yerli işgücü yerine Bursa ve çevresinde öbeklenen fabrikalarda olduğu gibi hem yönetim ve mühendislik kademesinde, hem de işçi statüsünde hep yurtdışı tercih edilmiş, işletmeler kurtarıcı olarak yabancı işgücünü görmüştü. Osmanlı yöneticilerinin bu başarısızlığı, belirleyen bir ekonomiye sahip olmaktan maruz kalan bir ekonomiye dönüşmeyi beraberinde getirmişti.

Tarım ve dokumacılıktan sonra en geniş pavyon ateşli silahlara ayrılan bölümdü. Burada ateşli ve kesici silahlarla, ordu araç ve gereçler sergileniyordu. Bunlar arasında top, obüs veya havan topu, süvari ve piyade tüfeği, tabanca, kundaklı bronz donanma topu, filinta ve deniz piyade tüfeği, kılıç, kama, süngü, kanca, mızrak ve ok gibi kesici ve delici silahlar, küçük çaplı savunma tüfekleri, miğfer ve çelik zırhlar, eski Türk tipi işlemeli tüfek ve tabancalar, fişeklik, av elbiseleri gibi ürünler yer alıyordu. Müzik bölümünde ise keman, piyano, korno bariton, trampet ve ney gibi müzik aletleri teşhir edilmiş ve en büyük ilgiyi piyanolar görmüştü (Önsoy 1983: 229).

Bu bölümde Tophane ve Zeytinburnu silah fabrikalarında üretilen mamuller yer alıyordu. Her iki fabrikada üretilen çeşitli çap ve markada 140 civarında ateşli silah sergide teşhir ediliyordu. Zeytinburnu Silah Fabrikası'ndan 4 top, 3 obüs veya havan topu, 50 süvari ve piyade tüfeği ile tabanca gönderilmişti. Tersane-i Âmire'den ise bir adet kundaklı bronz donanma topu, 50 adet filinta ve deniz tüfeği ile çeşitli tipte tabancalar gelmişti. Ayrıca Darbhane'de çalışan Mösyö Waren tarafindan geliştirilen üç yeni tüfek modeli de sergiye konulmuştu. Zeytinburnu Silah Fabrikası'nın yivli top numuneleri büyük ilgi toplamıştı. Osmanlılar daha 1840'larda Hafız Paşa'nın müdürlügü döneminde 14 yivli ilk topu yapmıştı. Özel sektörün silah sanayiindeki başarıları da sergide 60 tüfek ve tabanca ile yer alıyordu (Önsoy 1988: 89).

Sergide dikkat çeken pek çok eşya daha vardı. Bunlar arasında Halep, Şam ve Bursa ipek mensucatları Şark memleketlerinin kadim sınai eserlerinin nefasetini yansittyordu. Ayrıca Anadolu'nun Uşak ve Gördes ile Rumeli'nin Şehirköyü ve diğer bazı malum mahallerinde üretilen kaliçe ve keçeler de görmeye değerdi. Öyle ki bunların nakışları İran ve Avrupa keçeleriyle mukayese bile edilemezdi, çünkü "ziyade dayanıklılığ1 ve renklerinin gayet revnak ve sebatı cihetiyle" diğer ülkelerin keçelerine üstündü. Ayrıca özellikle Dersaâdet’te üretilen sırma işleri "gayet nefis"ti ve yabanc1 ülkelerde üretilen bu tür ürünlerin hiçbir eksiği yoktu (Münif Bey 1279: 364).

İslemiye Fabrikası'nda üretilen aba ve benzeri yün mensucat da çok kaliteliydi. Incili ve sırmalı renkli zenne terlikleri ise Dersaâdet'e özgü zarif ürünler arasındaydı. Tersane-i Âmire ve Tophane-i Âmire ürünleri de nitelikleri ve görkemleriyle göz alıcı bir yer işgal ediyordu. Sözgelimi Tersane-i Âmire'de üretilen maden ve ahşaptan pek çok gemi alet ve edevatı burada teşhir ediliyordu. Aynı şekilde Tophane-i Âmire'de imal edilen şeşhane toplar (altılı toplar) "şâyân-1 tahsin", yani takdir edilesi nitelikteydi ve Avrupa fabrikalarında üretilen ma'müllerden bir farkı yoktu (Münif Bey 1279: 365).

Kişisel yetenekleriyle çeşitli ürün örnekleri yapan ustalar da vardı. Mekteb-i Bahriye hocalarından Said Efendi’nin imal ettiği bir ürün de burada sergilendi. Bu ürün, demiryollarında kullanılan "lokomotif tabir olunur arabaların" dörtte biri ölçeğinde yapılmış bir modeliydi. Konunun uzmanları bu lokomotif modelini görünce hayranlıklarını ifade ediyorlardı. Dersaâdet'in ünlü kuyumcu ustalarından Malkunyan Usta da ağaç şeklinde bir çift gümüşşamdan imal etmişti ki, görenler bunun Avrupa işi ürünlerden hiç farkı olmadığını kabul ediyorlardı. Bu arada Mektebi Harbiye öğrencileri de resim sanatının çocukluk dönemini yaşadığı ülkemizde, nefis resim 
örnekleriyle sergideki yerlerini alıyorlardı. Aznavuroğlu'nun kömür tozundan imal ettiği mürekkep de sergide yerini alıyor, böylece madenlerde ve kömür satış mağazalarındaki "mikdar-1 külli toz" telef olmaktan kurtarllıp ekonomiye kazandırılıyordu (Münif Bey 1279: 365-366).

Tüm ürünler övgüye değer değildi. Münif Bey gibi ziyaretçiler, gördükleri bazı ürünleri eleştirmekten geri kalmamıştı. Buna göre tüfenkçi esnafindan birinin yaptığı oldukça incelikli bir işçilik de bu eleştiriden nasibini almıştı. Tüfenkçi ustası "bir ince iğneyi boyuna delip içinden bir kıl geçirmişti." Kuşkusuz, bu durum söz konusu sanatkârın "kemal-i dikkat ve maharetine delalet eder ise de", böylesi bir yeteneği daha faydalı bir üründe kullanması daha makbul olacaktı. Bu nedenle de boşuna harcanmış bir yetenek olarak görülüyordu. Aynı şekilde bir hazerfen de yumurta üzerine nal resminde birtakım küçük demir parçaları mıhlamıştı. Ancak benzer eleştiri ona da şu şekilde yapılmıştı: "Böyle şeylere hüner denilse bile zann-1 acizânemize göre mahzâ abesle iştigaldir" (Münif Bey 1279).

\section{Fuarda Yer Alan Yabancı Ürünler}

Osmanlı'nın gücünü göstermeyi, tarım ve sanayide kat ettiği mesafeyi sergilemeyi amaçlayan sergide, sadece yerli ürünlerin teşhir edilmesi planlandı ise de, daha sonra bu düşünceden vazgeçildi. Avrupa ülkelerinde icat olunan yeni makine ve aletlerin sergilenmesine, bunun için ilave bir bina yapılmasına karar verildi. Verimli tarım toprakları bol olan Osmanlı için bu düşünce son derece önemliydi. Çünkü İngiltere ve Fransa'dan getirilen tarımda makineleşmeyi artıracak yabancı makinelerin sergide teşhir edilmesi, Osmanlılar tarafından kullanılmasını teşvik edecekti. Bu yüzden sergilenmek için eyaletlerden gelen mallarla birlikte yurtdışından getirilecek makine ve edevatın da gümrük vergilerinden muaf tutulmasina karar verildi ve bu husus Sergi Nizamnamesi'nde kayit altına alındı (Ceride-i Havadis 26 Ocak 1863). Avrupa'dan gelecek bu makinelerin gelişi ve çeşidiyle ilgili her türlü bilgi, aşama aşama gazeteler tarafından okuyucularına duyuruldu. Limana gelen makinelerin gümrükten geçtiği bile haber yapıldı (Ceride-i Havadis 2 Mart 1863).

Ayrıca Hükümet gazetelerde yayınlanan resmî bildirisinde, “Avrupa'da vapur (yani buhar) kuvvetiyle ve diğer usul ve kolaylaştırıcı vasıtalar kullanılarak işletilen tezgâhlarda meydana gelen çeşitli emtianın eski usule göre el ile imal olunan eşyanın yarısı pahasına, belki de daha aşağı (ucuza) çıkarıldığına" dikkat çekiyor ve "Osmanlı meslek ve sanayi erbabının dahi bu icatları kendi gözleriyle görüp ürünlerin gelişim sebebi ile bunun doğru vasıtalarını anlamalarını sağlamak" için "Avrupa'da meslek ve sanayi için yeni icat olunmuş kullanımı kolay bazı makine ve edevatı" sergilemek isteyenlere imkân tanınacağını beyan ediyordu. Anlaşılan oydu ki, Bab-1 Âli, kendi meslek ve sanayi erbabının Avrupa'daki son teknolojik gelişmeleri takip etmelerini, hatta bizzat görmelerini sağlamak, onların bu aletlerin faydalarını anlayıp kullanmalarına katkıda bulunmak için yabancı makinelerin, ama özellikle de tarım alet ve edevatlarının sergide yer almasına büyük önem veriyor ve bu amaçla da sergi civarında münasip bir yer düzenlemeye karar veriyordu (Tasvir-i Efkar 30 Kasım 1862). Tüm Osmanlı basını yukarıda ibareleri neredeyse harfi harfine tekrar ederek, "özellikle ziraat âlât ve edevatı fevka'l-gaye faideli ve kullanışı bulunduğu cihetle emr-i ziraat ve sınaatın terakkisine medar olacağı gibi vesâil-i nafianın bulundurulması fevâide-i külliyeyi mucib" olacağına vurgu yapıyorlardı (Kadri Bey 1863: 338).

Sergide teşhir edilmek için İstanbul'a İngiltere ve Fransa'dan makineler ile tarım aletleri getirildi (Giz 1968: 24). Bu makine, alet ve sanayi mamullerine ayrılan pavyon, serginin açıllş tarihine yetişememiş ve resmî açliştan tam 45 gün sonra 13 Nisan günü açılmıştı. Ne var ki, pavyonla birlikte yapımına başlanan kazan dairesi tamamlanamadığından ancak yanında buhar makinesi olan makinelerin çalıştırllıp ziyaretçilere gösterilmesi mümkün oldu (Giz 1968: 25).

Osmanlı İmparatorluğu'nun ilk kapsamlı millî sergisi olma özelliği taşıyan Sergi-i Umûmî-i Osmanî hakkında dönemin Osmanlı basınında detaylı bilgi ve duyurular yayınlanmıştı. Aynı yıl aylık olarak yayımlanmaya başlanan ve Cemiyet-i İlmiye-i Osmaniye adına sahipliğini Münif Efendi’nin üstlendiği Mir’at Gazetesi de sergi haberlerine geniş yer ayırdı (Kolay 2013: 265). Gazetenin 
Ramazan 1279 (Şubat 1863) tarihli nüshasında, Sergi Nizamnamesi'nin geniş bir özeti verildi. Aynı şekilde serginin yabancı ürünler bölümünde yer alan teknolojik ürünlerin tanıtımına büyük dikkat gösterildi. Bu bağlamda Şevval 1279 (Mart 1863) tarihli ikinci sayısında İngiliz sabanları tanıtıldı. Zilkade 1279 (Nisan 1863) tarihli üçüncü sayısında ise ziraat aletlerinin tanıtımı devam etti.

1863 Sergisi’ndeki sabanlar, büyük ilgi gördü. Mir’at gazetesinin Şevval 1279 (Mart 1863) tarihli ikinci sayısında bu sabanlardan sekizinin resimleri yer alıyor ve sabanların "meşhur (Ransem and Semz) nâm İngiliz kumpanyasının İngiltere'de (Ipsing) denilen mahalde bulunan (Oroel) kârhaneleri imalatından olup İngiltere'den Sergi-i Osmani'ye gönderilmiş olan ziraat alâtı meyanında" geldiği vurgulanıyordu. Bu sabanların kullanımı çok kolaydı, geleneksel sabanların kullanım şekline yakındı, hem beygir hem de öküz tarafından çekilebilirdi. Ancak kulllanım kolaylığının yanı sıra toprakta açtığı işleme derinliği diğerinin 1.5 katıydı. Ayrıca bu sabanların, "sap ve okları demirden mamul olduğundan dayanıklı bulundukları misillü öyle ahşap sabanlar gibi hararet ve rutubetten çekilip bozulmayacaklarından şüphe yoktu” (Mir'at Mart 1863).

Teşhir edilen sabanlar arasında iki veya üç hayvan tarafindan çekilen demir oklu büyük saban sayesinde ise çok kısa zaman içinde pek büyük bir arazi sürülebiliyordu, çünkü bu sabanın her bir hareketinde toprakta açtı̆̆1 derinlik, öncekilere nazaran birkaç kat genişlikteydi. Sergideki sabanlarla ilgili yazıyı kaleme alan muhabir, bu çeşit sabanlar ile ziraata ilişkin diğer aletlerin ülkeye gelmesi ve yaygınlaşmasıyla, Osmanlı'da hâlen kullanılan aletlerin iptal olacağı, yenilerin de üretimin artmasını sağlayacağına dair düşüncelerini okuyucuyla paylaşıyordu (Mir’at Mart 1863).

1863 Sergi-i Umûmî-i Osmanî’ye gönderilen ziraat aletlerinden en çok ilgi çekenlerden biri de "Ekin ve Ot Biçme Aleti” idi. Büyük bir tekerleği bulunan bu alette, büyük tekerlek döndükçe yanında bulunan küçük tekerlek de dönüyordu. Bu dönme anında birbirine bağlı bulunan üç köşeli bıçaklar iki yana oynayarak önüne gelen ot ve ekini biçiyor, ayrıca biçilenleri de büyük tekerleğin döndügü taraklar vasitasıyla da demet demet geri atıyordu. İngiltere'den gelen bu alet ile "saatte bir İngiliz dönümü kadar yer biçileceği Avrupa'da tecrübe" olunmuştu. İki beygir veya sığırın çekmesiyle çalışan bu alet, bir kişi tarafindan rahatça idare ediliyordu (Mir'at Nisan 1863).

Sergi-i Umûmî-i Osmanî’nin yabancılar için ayrılan pavyonunda ise "tek ve çift demirli pulluklar, harman makineleri, dövenler, tırpanlar, değirmenler, süt sağma makineleri, pamuk temizleme ve balya makineleri, tek ve çift tekerlekli el arabaları, sulama motorları gibi ziraat makineleri ve aletleri, tekerlekli yangın tulumları, Viyana menşeli bıçkı, keser, çekiç, testere, rende, törpü, bıçak, terazi, kantar ve para kasaları" bulunuyordu. Aynı bölümde yerli alet ve edevat da yer alıyordu. Bunlar dokuma tezgâhları ile çeşitli iş kollarında kullanılan alet ve edevattan mürekkepti (Önsoy 1983: 231).

Diğer aletler arasında çoğu Fransız ve İngiliz firmalarına ait olan küçük baş hayvanların kulaklarına işaret koymakta kullanılan makineler, ot kıyma ve pamuk balyalama makineleri bulunuyordu. Fransız ve İngiliz yapımı yedi beygir gücünde 4 hareketli motor da bulunuyordu. Bu motorların tamamı satıldı. Pavyonda bu aletleri tanıtmak, kullanımını göstermek ve denemek üzere yabanc1 teknik adamlarla mühendisler de hazır bulundu. Yabancı makine ve aletler, Imparatorlukta ilk kez gösterildikleri için büyük ilgi görmüş, neredeyse yerli ürünleri gölgede bırakmıştı (Önsoy 1983: 232). Tasvir-i Efkâr Başyazarı Şinasi'nin tabiriyle "Avrupa emtiasının revâcı Memâlik-i Osmaniye ma'mûlâtını adeta gûşe-i nisyanda bırakmış" idi (Tasvir- Efkar 30 Kasım 1862).

İngiltere'den sergiye gönderilen "dövülmüss demirden mamul ve sapları çelik olan çift aletleri”" 3.300 kuruştan, "her cins tokmak, ziraata mahsus aletlere bir hayvan kuvvetiyle ilave olunur alet" 5.500 kuruşa, "dövülmüş demirde mamul tarak" 400 kuruşa, "ekin biçme aletleri" 3.300 kuruşa, "zahire savurma makineleri”" 1.430 kuruşa, "bu makine ve aletleri çevirmek için dolap" 1.660 kuruşa, "üç beygir kuvvetiyle çalışır, saatte 30 İstanbul keyli zahire öğütür harman aletleri”" 5.500 kuruşa, "saman kesmek için çift bıçaklı makine" 400 kuruşa, "hayvan yiyeceği için zahire kırmak, bulgur yapmak için makine" 650 kuruşa, "tütün kırmak için makine" 400 kuruşa, "saatte 
sekiz kıyye elenmiş un çıkarır el değirmeni" 990 kuruşa, "bir beygir kuvvetinde buhar makinesi" 8.800 kuruşa satılıyordu. Ayrıca bu makinelerin 20 beygir kuvvetine kadar olanları da mevcuttu ve kuvvetleri arttıkça fiyatları da yükseliyordu (Ruzname-i Ceride-i Havadis 6 Haziran 1863).

\section{Yabanc1 Ürünler Pavyonundaki Yerli Ürünler}

Diğer taraftan yabancı ürünler pavyonunda bazı yerli ürünler de sergileniyordu. Bu ürünler arasında oldukça ilginç mamuller de vardı. Sözgelimi Tersane-i Âmire'de üretilen 4 kürekli ve beyaz tenteli gayet nefis bir sandal bunlardan biriydi. Dolayısiyla 1867 Sergisi, Türkiye'de yelkencilik ve bot sergilerinin ilk örneği de kabul edilebilir. İstanbullu sandıkçı Ali Bey'in el üretimi kalburları işçiliği ile göz dolduruyordu. El ile idare olunan bu kalbur, İngiliz yapımı kalburlar gibi iş görür nitelikteydi. Türk yapımı ilk yayıklar da burada teşhir edildi. "Yağ çıkarmaya mahsus küçük dolap" olarak adlandırılan bu aletin içine süt konuluyor, sonra el ile döndürülerek yağ ile ayranın birbirinden ayrılması sağlanıyordu.

Osmanlı İmparatorluğu'nun birçok eyaletinden sergiye gönderilen her renk sahtiyan ve meşin (deriler) de sadece yerli ziyaretçilerin değil, Avrupa'dan gelen misafirlerin de ilgisini çekti. Numuneleri çok beğenen Avrupalılar takdirlerini belirtip gerekli bağlantı için temasa geçtiler. Ayrıca Osmanlı topraklarından çıkartılan 30'a yakın farklı cins ve renkte mermerler de ilgi odağı oldu. Bu mermerler kaliteleriyle dikkat çekmelerinin yanında bu mermerlerden yapılmış "ocaklar", yani şöminelerin bulunması dekoratif bütünlük sağlamıştı.

Avrupa'dan getirtilen makine ve aletler, sergi kapanmadan önce Serdar-1 Ekrem Ömer Paşa'nın Küçükçekmece civarındaki çiftliğinde, diğer devlet adamlarının da hazır bulunduğu bir ortamda tecrübe edildi. Bu tecrübe neticesinde, söz konusu alet ve makineler, çok faydalı bulundu, ülke tarımının gelişimi için temin edilmesinin gerekli olduğu fikrinde görüş birliğine varıldı (Ergin 1995: 710).

Bu tecrübe ile yerli ve yabancı aletlerin kıyas edilmesi Osmanlı basınına da yansıdı. Sözgelimi Ceride-i Havadis, Ömer Paşa'nın çiftliğinde gerçekleşen tecrübe sırasında Türk ve Avrupa makinelerinin mukayese edildiğini yazıyordu. Habere göre "illk önce yerli yapım büyük bir çift aletine, altı çift öküz koşularak tecrübe edilmiş, aletin çeliğinin iyi olmaması ve toprağın fazla kurak olmasından dolayı hiçbir netice alınamadığı görülmüş, daha sonra tecrübe edilen İngiliz çift aletine iki öküz koşulduğu hâlde çeliğinin mükemmelliği ve diğer özellikleri sebebiyle istenilen netice" alınmıştı (Ceride-i Havadis 27 Temmuz 1863).

Ziraatte makine kullanımının Osmanlılar tarafindan tam benimsenip benimsenmediği tartışmalı bir konudur. Bazılarına göre, bu makineler, daha çok fuarlarda sergilenmek için ülkeye geliyor, sonra da çiftlik hangarlarına kaldırılıyordu. Çünkü Avrupa ile aramızda temel bir farklılık vardı. Buna göre Avrupalı köylüler, çoğalan fabrikalara koşturmuşlardı. Oysa tarım mahsullerini işleyen fabrikaların, külliyetli miktarda bu ürünlere ihtiyacı vardı. Fabrikaların ihtiyacı olan mahsuller ise ancak tarımda makineleşmeyle, yani az insan istihdamıyla kullanılan makineler sayesinde çok daha büyük verim ve ürün elde etmekle karşılanabilirdi. Ama bu makinelerin oldukça pahalı olması, çiftçi tarafindan yaygın bir şekilde kullanılmasını engelliyordu. Bu nedenle "Maatteessüf birkaç bin lira ile ancak satın alınabilen bu makinelerden az sermayeli çiftçiler müstefid olamıyorlar." $\mathrm{Bu}$ sorunun çözüm yolu ise çiftçilerin kumpanya teşkil ederek ya da mevcut kumpanyalardan biriyle sözleşme imzalayarak ücret mukabilinde arazilerini sürdürmeleriydi (Felahat Mecmuası 14 Haziran 1913).

\section{Sergi Ürünlerinin Üniversiteye Gönderimi}

Sergide yer alan Avrupa fabrikalarından gelen ürünler için bir başka yöntem daha izlenmişti. Buna göre 1863 Sergisi'nde teşhir edilip henüz satılamayan ürünler "numune ve model alınmak" üzere Dâr'ül-fünûn binalarına nakledilip burada muhafaza ediliyordu. Bu kapsamda yer alan zirâat alât ve edevâtının bedeli olan 271.190 kuruşun da, Ticaret Nezareti'nin müracaatı üzerine, 
Padişah'ın iradesiyle Maliye hazinesinden ödenmesi kararlaştırlliyordu (BOA, A.MKT.MHM, 279/70).

Diğer taraftan serginin bitimini takiben Avrupa'dan gelen ziraat ve sanayi makinelerinden çift edevatının muhacirlere verilerek arazide kullanılması düşünüldü. Ticaret Nezareti'ne bu yönde yapılan öneride, tarım arazilerinin muhacirler tarafından daha verimli kullanılmasını sağlayacak çift edevatının akçesinin de "muhâcirîn tahsîsâtından" ödenmesi teklif ediliyordu. Vidin Mutasarrıflığ1 da her çeşit makineden birer ikişer adedinin gönderilmesini yazıyla talep etmişti (BOA, A.MKT.MHM, 311/52).

\section{Serginin Getirdiği Yenilikler}

1863 Sergisi ile birlikte İstanbul halkı, günümüzde metro, tramvay, tren gibi toplu taşıma araçları, işyeri girişleri, stat girişleri ve sergi alanlarında uygulanan turnike sistemiyle tanıştı; sergi İstanbul'da turnikeli geçiş sisteminin ilk uygulandığ yer oldu.

Serginin ilk günlerinde giriş yapan ziyaretçilerin sayısının doğru bir şekilde öğrenilmesi için önce bilet yöntemi kullanıldı. Ancak Avrupa'ya sipariş edilen turnikelerin gelmesiyle bu yöntemden vazgeçildi ve turnike sistemi ana giriş kapısına yerleştirildi. Turnikeler "âlât-1 mahsusa" olarak isimlendirilip "işbu aletler pek faideli ve tuhaf bir şey" diye nitelendirilerek şöyle tarif ediliyordu: Alet, zeminden 1.5 endaze $^{4}$ yüksekliğinde ufkî olarak haçvari konulmuş bir dolaptan ibaretti. Duhuliye ücretini verdikten sonra içeriye girecek adam işbu dolabın bir kolunu vücuduyla iterek öte tarafa geçiyordu. Böylece her bir adam kolu ittikçe dolabın aşağı tarafinda ve kilitli bir küçük sandık içine konulmuş özel aletler tabiatıyla rakam işletiyordu. Bu şekilde hile ve fesat karışmadan ne miktar adamın giriş yaptığı sahih bir şekilde malum oluyordu (Münif Bey 1279 :367).

Yenilikçi ürünler özellikle Avrupa ülkelerinden gelen ziraat aletlerinde yoğunlaşmıştı. Yabancı ürünler pavyonunda teşhir edilen ve büyük ilgi gören, ziraata ve ev ihtiyaçlarına ilişskin bu alet ve edevatın bazıları şöyleydi (Münif Bey 1279a: 409 - 413):

Buğday ve arpa başaklarm toplayn samandan ayırmaya mahsus 7-8 beygir kuvvetinde bubar makinesiyle idare olunan döven: $\mathrm{Bu}$ dövenin bir veya iki çift hayvan ile kullanılan küçükleri de bulunuyordu. $\mathrm{Bu}$ alet, bin bir zahmet ile harman dövüp savurmak için rüzgâr beklemeye son veriyordu. Aleti çalıştıran buhar makinesi tekerlek üzerinde olduğu için istenilen mahalle kolaylıkla nakledilebiliyordu.

Mubtelif sekeil ve büyüklü̈kte değirmenler: Hayvan ya da el ile idare olunabiliyordu. Değirmen buğdayı öğütüp kepeğini ayırıyor, unu da birkaç cinste çıkartabiliyordu. Seyyar nitelikte olan bu değirmenler arzu edilen yere taşınabiliyordu. Ayrıca hayvanlar için hububat karmak veya bulgur yapmak için de çeşitleri bulunuyordu.

Silindir kalbur: El ile idare olunan bu kalburların delikleri istenilen derecede ince veya kalınlaştırılabiliyordu. Taş ve benzeri şeyleri yukarıdan, tuz ve samanı da bir yanından çıkartıyordu.

Inek sağmaya mabsus alet: Yeni icat olan bu alet, ineğin dört memesine takılarak sağma işlemi yapılır. Dakikada hayli miktar süt çıkarılır, hayvan bu aletten rahatsız olmaz. Amerika ve İngiltere'de bunun kullanımına büyük rağbet vardır. Zaten alet, 1863 Sergisi'nden bir y1l önce düzenlenen Londra Dünya Sergisi’nde çok büyük beğeni toplamış ve mucidine de ödül kazandırmıştı.

Pamuğu denk yapan alet: Uzak mahallere nakledilecek pamuğun gemide ya da arabada geniş yer işgal etmemesi için, denk yapılması gerekir. İşte bu alet, pamuğun hacmini küçülterek denk hâline getirmektedir.

Tekerlekli yangin tulumbasi: İki hortumlu olan bu tulumbanın bir hortumu ile yangina su sıkılırken, diğer hortum bir havuz ya da kuyuya salınarak tulumbaya su sağlanır.

\footnotetext{
${ }^{4}$ Endaze, Osmanlı devrinde kullanılan 65 cm uzunluğunda bir ölçü birimiydi; 1 Nisan 1931'de kullanımdan kaldırldı ve metrik sisteme geçildi.
} 
İki tekerlekli demir arabalar: Çiftliklerde gübre, inşaatlarda taş ve toprak taşımak için kullanılabilir. Uygun yerde bu arabayı kullanan bir kişi, 5 adamın görebileceği işi görür.

Dikiş makinesi: $\mathrm{Bu}$ alet ile her türlü ince ve kalın mensucat üzerinde dikiş dikilebilir. $\mathrm{Bu}$ makine, 15-20 terzinin gördüğ̈ işi rahatlıkla görebilir.

Viyana işi demir kasalar: Dökme demirden yapıldıkları için oldukça dayanıklı ve kilitler ise çok usta işidir. Dolayısıyla kırılamazlar. Yangın olduğu zaman en şiddetli ateşin içinde 7-8 saat kalır ve hiç zarar görmezler. Çeşitli renklerde olan kasalar, evlerde ziynet eşyasının konulması için de kullanilabilir.

$\mathrm{Bu}$ sayılan ürünlerin dikiş makinesi ve Viyana işi demir kasalar hariç tamamı İngiliz yapımıydı. Buhar kuvvetiyle çalışanların sergi içindeki vapur (buhar) makineleriyle idare olunuyordu. El ile çalışan aletlerin yanında ise bir görevli bulunuyordu. Bu görevliler hem nasıl kullanıldığını gösteriyor hem de makine hakkında bilgi veriyorlardı.

Sergiye getirilen ürünler arasında en çok ilgiyi yukarıda da anlatıldığı gibi tarım aletleri ile un değirmenleri çekti. Her ikisi, ama özellikle de un değirmenleri İstanbul ticaret çevrelerinde büyük alaka uyandırdı. Çünkü un değirmenleri, tam da İstanbul'un artan nüfusuna paralel bir şekilde hızla yükselen ekmeklik un ihtiyacının tavan yaptığı bir sırada gündeme gelmişti. Hakikaten İstanbul'da gittikçe artan nüfusu beslemek için geniş ölçüde un imal eden değirmenlere ihtiyaç hâsıl olmuştu. Dolayısıyla un değirmenlerini teşhir ve satış amacıyla sergiye getiren fabrikaların, İstanbul'da sağlam haber kaynakları olduğu söylenebilir. Burada "değirmen", "çark ve makine” manasında kullanılıyor, "un değirmenleri" denirken de "buhar makinesiyle işleyen un değirmenleri" kastediliyordu (Şanda 1965b: 4).

Daha evvel de, sözgelimi 1839 yılında, artan un ihtiyaçlarını karşılamak için Boğaziçi’nin yüksek tepelerine un imal eden yel değirmenleri kurulmuştu. Dönemin basını da en önemli sorun olarak gördükleri un imalatını çözeceğine inandıkları değirmenlere büyük ilgi gösteriyor, sergideki un değirmenlerinin kapasite ve özelliklerini detaylı bir şekilde anlatan haberlere yer veriyordu. $\mathrm{Bu}$ haberlerden birinde, Mösyö Pigeon tarafından teşhir edilen değirmenin yüksek kapasitesi, ucuzluğu ve iyi kalite un yaptığı anlatılıyordu. Bu yeni değirmenlerin İstanbul'da işletmeye alınması hâlinde, "yabancı memleketlerden ithal edilen yüksek kalitedeki beyaz un ithaline lüzum" kalmayacakt1. Aslında bu tip bir değirmen ilk kez İstinye'de kurulmuştu. İstinye değirmeni, bir ay içinde 120 bin kile buğday öğütebiliyordu. Kayıtlara göre İstanbul ve havalisinin ihtiyac1 450 bin kileydi. Dolayısıyla tek başına İstinye değirmeni İstanbul'un ihtiyacının dörtte birini karşılayabiliyordu (Şanda 1965b: 4).

Yine Hasköy'de Yakup Bey isminde bir özel teşebbüs sahibi, 8 çift taşlı değirmen kurmuştu. Burada yeni bir sistem uygulandı. Çift taşlı değirmen sayesinde unun kalitesi bozulmadan yüksek oranda buğday öğütülebiliyordu. Benzer bir şekilde Corfi isminde bir tüccar da Cibali’de değirmen tesis etti. Aynı özellikleri taşıyan Cibali değirmeninde Channes Oksel motoru denilen bir değirmen bulunuyordu. Öyle ki, bu değirmen 80 değirmen taşının yaptığı işi 25 taşla tek başına yapabiliyordu. Üretimi artıran bu değirmen, ülkeye ilk kez Mösyö Michel isminde bir ithalatçı tüccar tarafindan getirilmişti. İşte sergide böylesine yeni teknolojiyi yansıtan ürünler sergilendi ve teşhir edilen bu değirmenler satıldı. $1863^{\prime}$ ten sonra İstanbul un ithal etmek yerine un işleyen bir yapıya kavuştu. $\mathrm{Ne}$ var ki gümrük vergi oranları o kerteye getirildi ki, artık buğday ithal etmektense un ithal etmek daha kârlı hâle geldi. Yeni kurulan değirmenleri Hükümet koruyamadı. Bu değirmenler birbiri ardına kapandı. 1914 yılında I. Dünya Savaşı başlayana kadar da kapalı kaldı (Şanda 1965b: 4).

\section{Serginin Yabanc1 Ziyaretçileri}

1863 Sergisi, Avrupa ülkeleri tarafindan yakından takip edildi. Bu takip iki boyutlu idi. Bir yandan serginin ziyaret edilmesi, bu gelişmelerin aktarılması söz konusu iken, diğer yandan da özellikle yeni üretilen buharlı makine ile tarım alet ve edevatları için yeni bir pazar oluşturma 
gayretleri bulunuyordu. Sergiyi “seyr ve temaşa etmek için Viyana'dan gelecek olanlar” 300 kişi olarak organizasyon firmasına isimlerini kaydettirmişlerdi (Ceride-i Havadis 2 Mart 1863).

Basına yansiyan bilgilerden Viyana'dan 142 kişilik bir kafilenin vapurla geldiği, 450 kişinin de yolda olduğu öğreniliyordu. Viyanalı sergi ziyaretçileri İstanbul'da 5 gün kalıp yine gemiyle Osmanlı'nın önemli ticaret merkezlerinden biri olan İzmir'e gideceklerdi. Oradan da Trieste'ye dönmeleri söz konusuydu (Ceride-i Havadis 4 Nisan 1863). Kafilenin İstanbul-İzmir-Trieste güzergâhı ortaya koyuyordu ki, ziyaretçiler ticaret amaçlı gelmişlerdi, buradaki görüşmelerin altyapısını İzmir ve Trieste ziyaretleri ile tamamlayacaklardı. Dolayısıyla Viyana'dan gelen bu topluluk, Osmanlı'nın ilk turist kafilesi olarak değil, Osmanlı'ya gelen ilk kapsamlı ticaret heyeti olarak değerlendirilmelidir. Bu ticari heyet içinde Viyana kumaş fabrikalarında usta olarak çalışan kişilerin de bulunması bu görüşü güçlendiriyordu. Kald1 ki, bu ustalar, Osmanlı kumaş dokumacılığını yakından görüp fikir sahibi olmak istiyorlardı. Ayrıca Osmanlılar bu kişilerin bilgi ve deneyimlerinden yararlanmak istiyorlardı, masraflarının Ticaret Nezareti tarafindan karşılanması da bunu gösteriyordu (Ruzname-i Ceride-i Havadis 5 Mart 1863).

$\mathrm{Bu}$ arada Fransa ve İngiltere iş çevreleri de Osmanl Sergisi'ni görmek üzere İstanbul'a geldiler (Ceride-i Havadis Nisan 1863). Sözgelimi 25 kişilik bir İngiliz kafilesi Nisan sonrasında, 15 kişilik Parisli fabrikatör ve iş adamlarından oluşan grup ise Nisan ortalarında İstanbul'a ulaştı. Amaçları hem sergiyi gezmek, hem kendi üretimleri için siparişler almak, hem de Osmanlı İmparatorluğu'nda üretilen malları yakından görmekti (Giz1968: 24).

İngiliz işadamları, İngiliz sanayisinin merkezi olan Liverpool'dan hareket eden gemiyle İstanbul'a gelmişler, daha sonra İzmir'e uğramışlar, Akdeniz sahilinden İskenderiye'ye giderek memleketlerine dönmüşlerdi (Nezihi 1931: 417). Dolayısıyla 1863 Sergisi, sadece Osmanlı tüccar ve üreticilerinin bir araya geldiği bir platform olmamış, Osmanlı yöneticileri, tüccarları ve üreticileri ile yabanc1 tüccar ve üreticilerin bir araya geldiği bir mekân görevi de görmüştü.

\section{Serginin Kapanışı ve Sergi Binasının Yıkılması}

Sergi-i Umûmî-i Osmanî, yaklaşık 5 ay açık kaldı. Böylece 27 Şubat $1863^{\prime}$ te büyük bir törenle açlan sergi, 1 Ağustos 1863'te kapandı. Sergiyi, 150 bin kişi ziyaret etti ve giriş ücreti olarak yaklaşık 450 bin kuruş gelir elde edildi. Ne var ki, bu gelir, masrafların ancak bește birini karşılayabildi. Sultan Abdülaziz, yapımı üstlenen şirketin zarar etmemesi için aradaki farkı kendi karşıladı (Tercüman-1 Ahval 7 Ağustos 1862). Sergilenen ürünlerin büyük kısmı ise satıldı. Ürünlerin satışına açıllsşından 11 gün sonra, Ramazan'in 20'sinden sonra başlanmıştı (Tercüman-1 Ahval 16 Mart 1863). Satılamayan ürünler ise devlet tarafından, sahiplerince belirlenen fiyat üzerinden satın alındı (Önsoy 1983: 234). Serginin sona ermesinden 2 yil sonra 1865'te sergi binas1 yıktır1ldı (Çelik 2005: 152).

Sergi binasının yıkılmasına karşı çıkanlar da oldu. 30 bin İngiliz lirasına mal olan ve mimarisi ve büyüklüğüyle Osmanlı'nın yeni ticaret tarzının simgesi olan sergi yıkımının yanlış bir uygulama olduğu dönemin gazetelerinde savunuldu. Bunlardan biri de Mecmua-i Fünun'da 'Sergi-i Umûmîi Osmanî2 adlı bir makale kaleme alan Kadri Bey idi. Kadri Bey'in bu makalesinde, At Meydanı'nda inşa olunan sergi mahallinin çok geniş olduğu, "bundan böyle birkaç defa daha açılacak sergiler için kâfi derecede" olduğu belirtiliyor ve "işitildiğine göre sergi kapandıktan sonra söz konusu binalar yıkılacağından, bu keyfiyet cümlenin üzüntüsüne sebep olmaktadır” diye yazılıyordu (Kadri Bey 1863: 433).

Dersaâdet gibi bir şehirde mutlaka geniş meydanlara ihtiyaç vardı ve Sultanahmet de bunlardan biriydi. Buranın sergi binası için daimî olarak kapatılması düşünülemezdi. Ancak İstanbul ahalisi, bu meydanı gerekli şekilde düzenlenmediğinden zaten kullanamıyordu. Dolayısıyla "söz konusu meydana yapılan binalar serginin bitiminde yıkılmayıp diğer muntazam bir sergi mahalli yapılıncaya kadar hâli üzere" bırakılmalıydı; çünkü "iki üç senede bir kere bu seneki gibi söz konusu mahalde sergi açılması münasib-i hâl ve muvafik-1 maslahat gibi” görünüyordu (Kadri Bey 1863: 
Kadri Bey, ekonomik gerekçelerle de düşüncesinin doğruluğunu ispat ediyordu. Bilindiği gibi bu sergi binaları 30 bin İngiliz lirasına, yani 6 bin 600 kiseye mal olmuştu. Yikıldığ takdirde enkaz bu masrafın sekizde birini karşılayacaktı. Bir anlamda bina kendini amorti etmeden yıkılmış olacaktı. Ayrıca yalnız bir kere sergi açmak, istenilen neticenin elde edilmesi için yeterli olmayacaktı. Doğrusu her iki üç senede bir kere bunun gibi bir sergi açılması lazımdı. Her sergi açılışında da bir çarşı, yani sergi binası açılması "hayli tekellüf ve masrafa muhtaç olacağı cihetle" sadece sergi binası yapma düşüncesi bile, sergi düzenlenmesine engel olacaktı. Elbette yukarıda açılanan sebeplerden dolayı sergi binasının daimî olarak muhafaza edilmesi caiz değildi. O hâlde "birkaç defa söz konusu mahalde yalnız Memâlik-i Mahruse mahsulât ve masnûatına mahsus sergiler küşad olunduktan sonra", İstanbul'da bir sergi-i umûmî açlacağı zaman münasip bir yere daha geniş ve muntazam bir sergi mahalli yapılırdı. Ancak bu sergi binası yapıldıktan sonra At Meydanı'ndaki sergi binasının y1k1lmas1 münasip olurdu. Sergilerin sadece İstanbul'a özgü kalmaması, diğer ticaret ve sanayi merkezi illerde de organize edilmesi Kadri Bey'in en büyük hayaliydi. Bu yüzden Hükümet'e İzmir, Selanik, Manastır, Şam ve Halep gibi sanayi ve ticaret merkezi şehirlerde her sene bir defa husûsî sergiler açılmasını tavsiye ediyor ve "memleketimizce ziraat ve sanaatın hangi şubelerinin ıslahı daha mühim görünüyor ise bunların arzu edilen şekilde 1slahı için" ödül konulmasını öneriyordu. Kadri Bey'e göre ehl-i sanat ve ziraatın teşvik ve rağbeti ancak bu şekilde mümkün olacaktı (Kadri Bey 1863: 433-434).

Kadri Bey'in önerisi Bab-1 Âli tarafından kabul edilmemiş olacak ki, sergi binası 1865 yılında, başkaca bir ulusal sergi açılmadan yıkıldı. Böylece İmparatorluk hem İstanbul'da daimî bir sergi alanına sahip olma firsatını, hem de üretimi etkileyecek, teknoloji transferini daha da hızlandıracak Batılı tarzda bir sergi geleneği oluşturma imkânını kaçıracaktı. Ta ki Sultan II. Abdülhamid Dönemi başlayana kadar.

Osmanlı aydınları içinde fuarların önemini kavramış, fuar geleneğinin yerleşmesi için daimî fuar mekânının gerekliliğini anlamış olanların itirazlarına rağmen Sergi-i Umûmî-i Osmanî binalarının yıkılması ve enkazının da alınarak inşa edilmekte olan Bâb-1 Seraskerî binalarında kullanılması gündeme geldi. Zaten Hükümet'in kararı da bu yöndeydi. Dolayısıyla bu karar, "Ebniye Komisyonu" tarafindan Nafia Nezareti ile Maliye Nezareti'ne bildirildi. Maliye Nezareti'nin bu konuyla ilgisi, Komisyonca bu enkaz için Niko Kavas Kalfa'nın ödemesi kararlaştırılan "bir yük altmışbeş bin akçe" bedelin tahsil edilmesinden ibaretti. Ayrıca enkaz bir ay içinde kaldırllıp mahal düzlenip tanzim ettirilecekti (BOA, A.MKT.MHM, 329/85).

Sadaret Makamı'ndan hazırlanıp gereği için Zabtiye'ye gönderilen bir yazı, Sergi-i Umûmî-i Osmanî binası için Osmanlı yöneticilerinin kararsız olduğunu gösteriyordu. Bu kararın taslak metninde “daha önce At Meydanı'nda yaptırılmış olan binaların boş durmasının münasip olmadığından yıkılması tasvip kılınmıs olmağla iktizasının ifası" diye bir hüküm cümlesi yer alıyordu. Ne var ki, hemen altına el yazısıyla "Pek uygun ise de bis-suâl takdim ile ba'de (sonra) yazıla" diye not düşülmüştü. Bu da yıkılması konusunda kesin bir fikrin henüz oluşmadığından ya kararı yazan tarafindan Sadrazam'a, ya da Sadrazam tarafindan Padişah'a sorulması hatırlatmasının düşüldügünü gösteriyordu. Ne yazık ki yöneticiler, yenisi yapılmadan bu sergi binasının yıkılmasına karar verip uygulayacaklardı. Daimî sergi binası arzusu Sultan II. Abdülhamid'in 1893'te başlatacağı teşebbüse kadar gündemden düşecekti. $\mathrm{O}$ yll başlayan hazırlıklar ise İstanbul depremi sebebiyle akîm kalacaktı (BOA, A.MKT.MHM, 397/38).

\section{Sergi-i Umûmî-i Osmanî’nin Sonuçları}

Sergi-i Umûmî-i Osmanî tam anlamıyla hedefine ulaşmıştı. Serginin sağladığı en önemli sonuçlardan biri Islah-1 Sanayi Komisyonu, diğeri de büyük şirketler kurulması fikriydi ki, her ikisi de o dönem için çok önemliydi. Bu nedenle derhal hayata geçirildi. Serginin sonuçlarını maddeler hâlinde şu şekilde sıralamak mümkündür (Önsoy 1988:8): 
İmparatorluğun dört bir yanından getirilip de sergide teşhir edilen ürünler bazı gerçeklerin idrak edilmesini sağladı. Şöyle ki, sergiye gelen 10 binin üzerindeki ürünlerin niteliği ve çeşidi, İmparatorluğun geniş bir hammadde kaynağına sahip olduğunu ortaya koyuyordu.

- Sadece bir tarım ülkesi olmadığı, sadece tarım bakımından kendine yeterli bir ülke olmadığı, aynı zamanda sanayi bakımından kendine yetebileceği, verimli topraklara sahip olunduğu herkesçe kabul gördü.

- Eyaletler arasındaki iletişimsizlik nedeniyle o güne kadar ithal edilen bazı malların yerli kaynaklardan karşılanabileceği anlaşıldı. Bir eyalette olmayan ama ihtiyaç duyulan ürünler, o alanda üretim yapan diğer eyaletten temin edilebilecekti.

- Yöneticiler açısından ise anlaşılmıştır ki, bazı bölgelerde üretilen mallarda ıslaha gerek vardı. Küçük çaplı müdahalelerle büyük sonuçlar ve verim artırımları sağlanabilirdi.

- Ayrıca sergi nedeniyle İstanbul'a gelen üreticiler, esnaf, sanatkâr ve işadamları hem birbirleriyle tanışmıs, hem de devlet yetkililerine sorunlarını aktarma firsatı bulmuşlardı.

- Sergide yer alan yabancı alet ve makineler görülünce anlaşıldı ki, Avrupa ülkeleriyle İmparatorluk arasında önemli ve büyük bir teknolojik mesafe vardı. Bunun kapatılması için büyük gayretler gösterilmesi gerekiyordu.

- Sergi dolayisiyla yabanci basin tarafindan Avrupa kamuoyunun dikkati Osmanli İmparatorluğu'na çekildi. Bunun neticesinde birçok siyasetçi ve iş adamı İstanbul'a geldi.

- Yerli mallar için yabancı ülkelerde pazar bulma şansı doğarken, Avrupa alet ve makinelerinin Osmanlı İmparatorluğu’nda istihdam edileceği anlaşıldı. Rifat Önsoy'a göre serginin amacina ulaşan önemli bir olay olduğu söylenebilir.

Rıfat Önsoy'un maddeleştirerek, bir araya topladığı serginin sonuçlarını dönemin Osmanlı yazarları ayrıntılı olarak ifade etmişlerdi. Bu aydınların başında Münif Bey gelir ki, dönemin dergilerinde yer alan değerlendirme yazılarında o ve diğer Osmanlı aydınlanı, beklentilerini sanayi ve ziraatın geliştirilmesi ve sslahının en güzel şekilde yapılabilmesi için gerekli tedbirlerin alınması olarak ortaya koyuyorlardı. Onlara göre bu ise, "elyevm" tarım ve sanayi ürünlerinde Osmanlı devletinin ne merkezde olduğunun belirlenmesi, hangi sektörlerdeki meslek ve sanayinin ihdas ya da 1slah olunacağının tespitiyle" mümkün olacaktı (Münif Bey 1279: 367).

Serginin diğer sonuçlarından biri de "ehli sanayie meydan-1 imtihan açmak" olarak öngörülmüştü. Böylece bazıları akranları arasından öne çıkacak, rekabet ve gayretleri artacak, mahsulât ve masnûatının niteliği üstün olanların seviyesine, belki daha da üstün bir mertebeye ulaşacaktı. Dolayısıyla sergi, her katılımcının yeteneğini (kuvve-i istidâdiyesini) göstereceği bir vesile-i hasene (güzel bir vesile) idi. Bu şekilde mevcut meslek ve sanayi ilerleyecek, hatta yeni buluşların ortaya çıkması mümkün olacaktı (Münif Bey 1279: 340).

Sergi, memlekette üretilen tarım ve sanayi ürünleri numunelerinin hepsinin bir mahalde görülüp diğerleriyle mukayese edilmesine imkân vermişti. Böylece eyalet ve sancak ahalilerinin yetenekleri anlaşılmıs, ayrıca ziraat ve zenaatın hangi şubelerinin ıslaha muhtaç olduğu ortaya çıkmıştı. İşte tüm bunların öğrenilip ortaya çıkmasında bu sergi, Hükümet için mikyas-1 sahih (doğru ölçü) olmuştu (Münif Bey 1279: 340).

Sergi, Osmanlı'nın en önemli tüketim merkezi olan İstanbul ile eyaletler arasındaki ticari iletişimin aktif hâle gelmesini, ihtiyaç duyulan ürünler hakkında doğru bir şekilde bilgi edinilmesini gerçekleştirmişti. Çünkü Osmanlı Devleti dahilinde üretilen, ancak İstanbul'da yaşayanlar tarafindan bilinmeyen her nevi eşya ve emtia bu sergi sayesinde görüldü. Mahallindeki fiyatı öğrenildi. Böylece payitaht ile eyalet halkları arasındaki alışverişin artmasına kaynak olacak büyük bir pazar görevi gördü. Osmanlı Devleti'nde aslında her türlü emtia ve erzak üretiliyordu. Ne var

${ }^{5}$ Elyevm, "günümüzde, bugün” anlamında kullanılmaktadır. 
ki bunlar İstanbul'a getirilemediğinden İstanbul ahalisi yabancı ülke mahsullerine muhtaç kalıyordu. Kuşkusuz bunun başlıca sebebi, nakliye vasıtalarının düzensiz olmasından kaynaklanan yüksek masraflard1. Doğrusu, 1863 Sergisi ile "İstanbul'da Avrupa malına rağbet olunup yerli meta kullanılmaz" şeklinde taşra ahalisi arasında yayılan boş fikirlerin kötü tesirleri de ortadan kalkmıştı (Münif Bey 1279: 340).

Fuarlar konusunda bir uzman olarak sözüne güvenebileceğimiz Salaheddin Bey, 1863 Fuar1 ile sergi komiseri olarak bulunduğu 1867 Paris Dünya Fuarı arasında geçen 4 yıl boyunca, çok daha objektif bir değerlendirme açısına sahip olmuștu. Ona göre, 1863 Osmanlı Sergisi, gerek katılımc1 açısından ve gerek sergilenmek üzere gönderilmiş olan ürünlerin üstünlüğ̈u bakımından tüm fuarlardan daha üstündü. Kaldı ki Sultan Abdülaziz Han, bu denli kısa bir sürede ülkesinin refah ve zenginliğini artırmak için çok büyük bir gayret ve teşvik ortaya koymuştu. Onun çabaları başlayana kadar fuarların kalkınmadaki önemi "göz ardı" edilmiş, Türkiye'nin potansiyelini ve Osmanlı üreticilerinin çabalarını fuarlarda göstermek mümkün olmamıştı. 1863 Sergisi'nin düzenlenmesi ve diğer uluslararası fuarlara katılan üreticiler arasında bir rekabet ortamının doğması ve ticaretin en son tekniklerinin kullanılması sağlanmıştı. Ayrıca fuarlar sayesinde üreticilerin hem sanayi hem de tarımsal ürünlerinin en kısa yoldan halka, yani tüketiciye ulaştırılması da hedeflenmişti (Salaheddin Bey 2008: 29-30).

\section{Kaynakça}

\section{Kitap ve Makaleler} Yayınlar1.

AYMANTUĞ, Yusuf (2006). Kongre Turizmi ve Fuar Organizasyonlar, Ankara: Detay

BAHÇETEPE, Tülay (2009). Fuarlara Katıllm Rehberi, İstanbul: İTO Yayınları.

ÇELIK, Zeynep (2005). Şarkem Sergilenişi, İstanbul: Tarih Vakfi Yayınları.

ERGİN, Osman Nuri (1995). Mecelle-i Umûr-ı Belediyye, C. II, İstanbul: İstanbul Büyükşehir Belediyesi Kültür İşleri Daire Başkanlı̆̆ı Yayınları.

GIZ, Adnan (1968). “1963 İstanbul Sergisi”, İstanbul Sanayi Odası Dergisi, 28: 23-25.

GÜÇER, Lütfi (1987). “Osmanlı İmparatorluğunun Ticaret Politikaları”, Türk İktisat Taribi Yullı̆̆r, İstanbul: İ̈̈ İktisat Fakültesi Türk İktisat ve İçtimâiyât Tarihi Araştırmaları Merkezi, 1: 5128.

GÜRAN, Tevfik (2011). İktisat Taribi, İstanbul: Der Yayınları.

Hakk1 Nezihi (1931). "Memleketimizde İlk Sanayi Sergisi”, İstanbul Ticaret ve Sanayi Odası Mecmuası, 7: 415-418.

Kadri Bey (1863). "Sergi-i Umûmi-i Osmanî”, Mecmûa-i Fünûn, 10: 430-434.

KILKIŞ, Yıldırım (1977). Uluslararası Fuarlar ve Türkiye, İstanbul: İTO Yayınları.

KOLAY, Arif (2013). “Türk Modernleşmesine Sergilerin Katkısı: 1909 Bursa Sergisi Örneği”, Türk Modernleşmesi, ed. Arif Kolay, ss. 263-288, İstanbul: Yeditepe Yayınları,

Münif Bey (1279). "Sergi-i Umûmî-i Osmanî’nin Vukû-1 Küşadı", Mecmûa-i Fünûn, Dersaadet, 9: 362-367.

Münif Bey (1279a). “Zamîme-i Sergi-i Osmanî”, Mecmûa-i Fünun, Dersaadet, 10: 408-413.

ÖNSOY, Rifat (1983). “Osmanlı İmparatorluğu'nun Katıldı̆̆1 İlk Uluslararası Sergiler ve Sergi-i Umûmî-i Osmanî (1863 İstanbul Sergisi)”, Belleten, 47 (185): 210-213.

ÖNSOY, Rifat (1988). Tan₹̨imat Dönemi Osmanl Sanayii ve Sanayilesme Politikasi, Ankara: Türkiye İş Bankası Yayınları. 
Salaheddin Bey (2008). Türkiye 1867 Evrensel Sergisi, Çev. Hakan Arca, İstanbul: İstanbul Fuar Merkezi Yayınları.

SÜMER, Faruk (1985). Yabanlu Pazar Selçuklu Devrinde Milletlerarası Büyü̈k Bir Fuar, İstanbul: Türk Dünyası Araştırmaları Vakfi Yayınları. 4-23.

ŞANDA, Hüseyin Avni (1965a). "Bizde İlk Ticaret Sergisi”, İstanbul Ticaret Gazetesi, 8 (368):

ŞANDA, Hüseyin Avni (1965b). "1863 Sultanahmet Sergisinin Sonuçları”, İstanbul Ticaret Gazetesi, 8 (371): 4-14.

ŞEN, Ömer (1996). Osmanl Panayrlar (18. - 19. Yürynl), İstanbul: Eren Yayınları.

http://wpedia.goo.ne.jp/enwiki/Panegyris, 15.03.2020.

\section{Gazete ve Dergiler}

Ceride-i Havadis, Numara 1128, 5 Şaban 1279 (26 Ocak 1863)

Ceride-i Havadis, Numara 1133, 11 Ramazan 1279 (2 Mart 1863).

Ceride-i Havadis, Numara 1138, 22 Şevval 1279 (4 Nisan 1863).

Ceride-i Havadis, Numara 1139, Gurre-i Zilkade 1279 (Nisan 1863).

Ceride-i Havadis, Numara 1142, 22 Zilkade 1279 (11 Mayıs 1863).

Ceride-i Havadis, Numara 1151, 10 Safer 1280 (27 Temmuz 1863).

Felahat Mecmuas1, Numara 6, 1 Haziran 1329 (14 Haziran 1913), ss. 83-84.

Mir'at Gazetesi, Numara 2, Şevval 1279 (Mart 1863).

Mir'at Gazetesi, Numara 3, Zilkade 1279 (Nisan 1863).

Ruznâme-i Ceride-i Havadis, Numara 561, 8 Şaban 1279 (29 Ocak 1863).

Ruznâme-i Ceride-i Havadis, Numara, 582, 10 Ramazan 1279.

Ruzname-i Ceride-i Havadis, Numara 585, 14 Ramazan 1279 (5 Mart 1863).

Ruzname-i Ceride-i Havadis, Numara 639, 18 Zilhicce 1279 (6 Haziran 1863).

Tercüman-1 Ahval, Numara 304, 11 Ramazan 1279 (2 Mart 1863).

Tercüman-1 Ahval, Numara 306, 15 Ramazan 1279 (6 Mart 1863).

Tercüman-1 Ahval, Numara 315, 25 Şevval 1279 (15 Nisan 1863)

Tercüman-1 Ahval, Numara 364, 10 Safer 1280 (7 Ağustos 1862).

Tasvir-i Efkâr, Numara 364, 10 Safer 1280 (27 Temmuz 1863).

Tasvir-i Efkâr, Numara 45, 7 Cemaziyelahir 1279 (30 Kasım 1862).

\section{Arşiv Belgeleri}

BOA, A.MKT.MHM, 329/21.

BOA, A.MKT.MHM, 242/63

BOA, A.MKT.MHM, 246/99.

BOA, A.MKT.MHM, 250/24.

BOA, A.MKT.MHM, 251/10.

BOA, A.MKT.MHM, 251/21.

BOA, A.MKT.MHM, 251/24.

BOA, A.MKT.MHM, 252/58. 
MEMİŞ, Şefik (2020). "Unutulanları Hatırlamak için Yapılan Fuar: 1863 Sergi-i Umûmî-i Osmanî (Osmanlı Genel Sergisi)", Mavi Atlas, 8(1): 189 - 214

BOA, A.MK'.MHM, 279/70.

BOA, A.MKT.MHM, 311/52.

BOA, A.MKT.MHM, 329/85.

BOA, A.MKT.MHM, 397/38. 